IZA DP No. 9114

Do Employment Protection Reforms Affect Well-Being?

Vanessa Dräger

June 2015 


\title{
Do Employment Protection Reforms Affect Well-Being?
}

\author{
Vanessa Dräger \\ University of Cologne \\ and IZA
}

\author{
Discussion Paper No. 9114 \\ June 2015
}

\author{
IZA \\ P.O. Box 7240 \\ 53072 Bonn \\ Germany \\ Phone: +49-228-3894-0 \\ Fax: +49-228-3894-180 \\ E-mail: iza@iza.org
}

\begin{abstract}
Any opinions expressed here are those of the author(s) and not those of IZA. Research published in this series may include views on policy, but the institute itself takes no institutional policy positions. The IZA research network is committed to the IZA Guiding Principles of Research Integrity.

The Institute for the Study of Labor (IZA) in Bonn is a local and virtual international research center and a place of communication between science, politics and business. IZA is an independent nonprofit organization supported by Deutsche Post Foundation. The center is associated with the University of Bonn and offers a stimulating research environment through its international network, workshops and conferences, data service, project support, research visits and doctoral program. IZA engages in (i) original and internationally competitive research in all fields of labor economics, (ii) development of policy concepts, and (iii) dissemination of research results and concepts to the interested public.
\end{abstract}

IZA Discussion Papers often represent preliminary work and are circulated to encourage discussion. Citation of such a paper should account for its provisional character. A revised version may be available directly from the author. 


\section{ABSTRACT}

\section{Do Employment Protection Reforms Affect Well-Being?*}

This paper examines reforms in German employment protection for permanent workers (EPLP) on workers' well-being proxied by life satisfaction. Using variation in how the reforms affected firms of different sizes, I apply a difference-in-differences approach in conjunction with individual fixed effects. I find that life satisfaction of temporary workers decreases by around 0.5 (11-point scale) when EPLP decreases. I investigate effect heterogeneity and discuss mechanisms. Placebo tests are conducted. An increase in EPLP had no effect. Due to the design of the EPLP reforms, the majority of permanent workers did not face major changes in EPLP.

JEL Classification: J32, J38

Keywords: employment protection reforms, well-being, life satisfaction, quasi-experiment, difference-in-difference

Corresponding author:

Vanessa Dräger

Wirtschafts- und Sozialwissenschaftliche Fakultät

University of Cologne

Albertus-Magnus-Platz

50923 Köln

Germany

E-mail: draeger@wiso.uni-koeln.de

\footnotetext{
* The major part of this paper was written while I was at the Institute for the Study of Labor (IZA), Germany. I would like to thank my former colleagues at IZA, participants at the SMYE 2014, AIEL 2013, EALE 2013, and HEIR 2013, David Jaeger, Astrid Kunze, Álvaro A. Novo, Andrew Oswald, Andreas Peichl, and Enrico Rettore.
} 


\section{Introduction}

Employment protection legislation for permanent contracts (EPLP) is a potential source of a high incidence of temporary employment and of youth unemployment (Kahn, 2007). In order to decrease adverse effects, liberalizing reforms in EPLP were proposed in the public debate in the aftermath of the 2007 financial crisis. Following this discussion, some European countries liberalized EPLP between 2008 and 2013, e.g., in Portugal, Spain, Italy, and Greece (OECD, 2013). Such reforms are considered to be politically harmful because powerful permanent workers would suffer, while less powerful temporary workers would benefit (e.g. Rueda, 2005).

Previous research on the effects of EPLP, however, suggests that the effect of EPLP on well-being is not as clear. Search and matching models predict that job destruction and construction of permanent jobs increases when EPLP decreases. Marinescu (2009) and Boockmann, Gutknecht, and Steffes (2008) show that job stability might decrease. In moral hazard situations, a decrease in EPLP could decrease monitoring, as dismissals can be applied as disciplinary advices, and thereby, decreases stress (Lepage-Saucier and Wasmer, 2012). Hence, for permanent workers less job stability must be weighed against the reduced stress. Due to increased job construction, temporary workers could benefit from a more likely access into permanent jobs (Centeno and Novo, 2012). Booth, Francesconi, and Frank (2002) showed that temporary work is associated with lower training, lower wages and less job satisfaction compared to permanent work. Workers, however, who remain in a temporary job after a reduction in EPLP might suffer due to the comparison to colleagues who transitioned into a permanent job.

In order to improve our understanding on effects of EPLP on well-being, I evaluate the effect of an increase and a decrease in German EPLP on life satisfaction as a proxy for well-being. The identification strategy relies on German EPLP reforms which changed EPLP for small firms only. Due to this subgroup and time variation, I am able to employ the reforms as quasi-experiments in a difference-in-difference approach (DID). As a major share of permanent workers was almost not affected by the reforms in EPLP, the focus is on temporary workers. Using the longitudinal German Socio-Economic Panel (GSOEP), I account for individual fixed effects.

A major drawback of the GSOEP, however, is that the treatment group can not be measured precisely, and hence, incorporates measurement errors. It is, therefore, likely that the estimates of the effect of EPLP on well-being are biased towards zero. This has to be kept in mind when interpreting the results. Importantly, in order to address potential violation of the common trend assumption, e.g. due to 
worker selection, I control for life satisfaction relevant observable and time-invariant unobservable heterogeneity such as age, age squared, and children. Hence, if the reforms induce worker selection, I capture for this, if the process can be explained by observable or time-invariant unobservable heterogeneity, but not if driven by time-variant unobservable heterogeneity. Furthermore, I conduct placebo tests as well as pre-treatment trend tests.

This paper contributes to the growing literature which employs evaluation techniques to study effects of labor market institutions and policies on well-being (e.g. Hamermesh, Kawaguchi, and Lee, 2014; Dorsett and Oswald, 2014). Within this literature, this paper is the first that combines standard evaluation techniques for the effect of reforms in employment protection on objective outcomes ${ }^{1}$ with the literature on determinants of life satisfaction. ${ }^{2}$ Boarini, Comola, Keulenaer, Manchin, and Smith (2013) and Ochsen and Welsch (2012) analyze the relation between employment protection and life satisfaction based on within-country variation of employment protection and pooled cross-sectional data but do not investigate withincountry subgroup variation. ${ }^{3}$ Thereby, they cannot easily rule out concerns about unobserved confounding and reversed causality. ${ }^{4}$ Busk, Jahn, and Singer (2015) (DID with propensity score matching), Lepage-Saucier and Wasmer (2012) (DID) and Kuroki (2012) (DID) are exceptions in the literature of employment protection and well-being. They examine the effect of employment protection on stress (LepageSaucier and Wasmer, 2012) and job satisfaction (Busk, Jahn, and Singer, 2015; Kuroki, 2012) but not on life satisfaction.

Furthermore, this paper is the first to study the effect of employment protection for permanent workers on life satisfaction. Boarini, Comola, Keulenaer, Manchin, and Smith (2013) and Ochsen and Welsch (2012) do not differentiate between protection for permanent versus temporary contracts. Other studies on employment protection and well-being which account for this difference investigate job satisfaction, perceived job security and stress but not life satisfaction (Lepage-Saucier and Wasmer, 2012; Salvatori, 2010; Clark and Postel-Vinay, 2009; Kuroki, 2012).

The main finding is that the decrease in EPLP in 1996 decreased life satisfaction

\footnotetext{
${ }^{1}$ For instance, Leonardi and Pica (2013), Scoppa (2010), Martins (2009), Kugler and Pica (2008), Boockmann, Gutknecht, and Steffes (2008), and Bauer, Bender, and Bonin (2007).

${ }^{2}$ For instance, Frey and Stutzer (2012), Clark and Senik (2010), Kassenboehmer and HaiskenDeNew (2009), and Clark, Diener, Georgellis, and Lucas (2008).

${ }^{3}$ Salvatori (2010) and Clark and Postel-Vinay (2009) investigate employment protection and job satisfaction or job security but do not investigate within-country subgroup variation, too.

${ }^{4}$ Reversed causality is a potential crucial issue as, for instance, workers who are worried about job security demand, as a consequence, higher EPLP from political actors (Clark and Postel-Vinay, 2009).
} 
of temporary workers by $6 \%$ of the mean in life satisfaction. An explanation for this is that temporary workers who remain in a temporary job suffer from the comparison to colleagues who successfully transitioned into a permanent job after the decrease in EPLP. This interpretation would be in line with the finding of Centeno and Novo (2012) that EPLP adversely affects transition probabilities from temporary to permanent work and would be in line with the literature on social comparison (e.g. Clark and Senik, 2010). Concerning the common trend assumption, I do not find that control and treatment group follow a different trend in the pre-reform period controlling for a broad set of observable and time-invariant unobservable heterogeneity. Furthermore, I find that less employable workers are specifically strong affected by a decrease in EPLP. The negative effect returns back to zero after one year which might be explained by adaptation (e.g. Clark, Diener, Georgellis, and Lucas, 2008). I find no effect of the increase in EPLP (1999) on temporary workers which could be explained by the notion that losses are valued stronger than gains (e.g. Boyce, Wood, Banks, Clark, and Brown, 2013). As the majority of permanent workers were not strongly affected by the EPLP reform, I do not expect effects on their well-being. Indeed, I do not find any. Due to the measurement error in the treatment status, however, all effects should be considered as lower bounds.

The paper is organized as follows: The next section develops hypotheses on the effect of employment protection on well-being and mechanisms. Following that, I present the institutional background in Section 3. The fourth Section introduces the identification strategy and data. Section 5 presents the results of the empirical analyses, and in the final section, I conclude.

\section{Related literature}

Employment protection regulations regulate the hiring and firing of workers with temporary contracts and/or with permanent contracts. A temporary contract finishes after a specified period of time, while a permanent contract is open-ended in its duration. These employment protection regulations are based on formal legislation, collective bargaining, and court interpretation of legislation. In this paper, I focus on formal employment protection legislation for permanent contracts (EPLP), regulating issues like the period of notice for termination, specific forms of dismissal, or severance payments. Thereby, stronger EPLP increases adjustment costs of the workforce at the firm-level.

In labor economics, firm-level adjustment costs are often modeled in dynamic 
labor demand models (e.g. Boeri and Garibaldi, 2007; Nunziata and Staffolani, 2007) and in search and matching models (e.g. Cahuc, Charlot, and Malherbert, 2012; Boeri, 2011). This literature suggests that employment protection has an effect on job destruction and creation, flows into and out of employment, but an ambiguous effect on employment levels. ${ }^{5}$

Relying on labor economics and the empirical literature on well-being, I derive hypotheses on the effect of EPLP on well-being. Well-being is considered to be a function of current income, expected income, and relative social status. The expected well-being from a permanent job is assumed to be higher than from a temporary job as workers in a temporary job exhibit a higher probability of becoming unemployed in the future.

\subsection{Employment flows}

Search and matching models incorporate employment protection via firing costs, which alter the profit function of firms. Boeri (2011) models the effects of an increase in firing costs for permanent workers in a labor market which allows the existence of temporary and permanent contracts in his model. An increase in firing costs yields a decrease in job destruction of permanent workers and a decrease in the conversion of temporary jobs to permanent jobs. Employing micro-level data and reforms which increased EPLP, Kugler and Pica (2008) find that separation from and access to permanent work decreases, Centeno and Novo (2012) show that transition probabilities decreased, Boockmann, Gutknecht, and Steffes (2008) show that job stability increased, and Marinescu (2009) finds a decrease in the firing hazard.

Based on these findings, a change in EPLP could affect well-being in several ways. Some temporary workers might benefit from a decrease in EPLP by actually transitioning from a temporary into a permanent job where expected income is higher. ${ }^{6}$ Workers who remain in a temporary job might benefit from higher probability of access into a permanent job in terms of employment prospects which may then increase the expected income of temporary jobs. I refer to this positive effect of a decrease in EPLP on well-being as the transition hypothesis. Temporary workers also, however, might suffer from a decrease in EPLP because the protection of their

\footnotetext{
${ }^{5}$ For an overview of the literature, see Cahuc and Koeniger (2007) and OECD (2013). Furthermore, a reduction in EPLP might have an effect on productivity (Cappellari, Dell'Aringa, and Leonardi, 2012) and might either increase (Lazaer, 1990; Leonardi and Pica, 2013) or decrease (Lindbeck and Snower, 2001) the wages of permanent workers.

${ }^{6}$ Booth, Francesconi, and Frank (2002) show that temporary compared to permanent jobs are associated with lower wages, job satisfaction and training opportunities.
} 
future job decreases (Salvatori, 2010): anticipation hypothesis. Due to the decrease in EPLP, permanent workers might perceive an increase in both the probability of separation from their jobs and the probability of transitioning into unemployment or into a temporary job so that the expected income of permanent jobs would decrease. $^{7}$ I refer to this negative effect on permanent workers' well-being of a decrease in EPLP as the insecurity hypothesis.

Relative social status might change as well. The relative status, e.g. in terms of relative income, is a crucial determinant of well-being, which was shown in the empirical literature on well-being and in behavioral economics (e.g. Karacuka and Zaman, 2012; Clark, Diener, Georgellis, and Lucas, 2008; Luttmer, 2005; Falk and Knell, 2004). A milestone in the literature on well-being and relative positions was the seminal article of Easterlin (1974). Despite substantial increases in wealth and the finding that income is positively related to well-being across countries and across individuals within countries, he finds no substantial increase in happiness within countries. $^{8}$ In order to explain this "paradox", social comparison and adaptation are discussed as potential explanations. Concerning social comparison, Clark and Senik (2010) show that income comparison is highly relevant for well-being and that people often compare themselves with their colleagues. When EPLP decreases, an increased amount of temporary colleagues might improve their status by moving into a permanent job. Hence, temporary workers who remain in a temporary job after the reform are worse off than former temporary colleagues who transitioned into a permanent job. Thus, a decrease in EPLP could decrease the temporary workers' well-being who remained in a temporary job through the mechanism of comparison. In the following, I refer to this argument as the comparison hypothesis.

\subsection{Moral hazard and monitoring}

EPLP might also change monitoring of permanent workers. In a moral hazard situation between permanent workers and employers, dismissals can serve as disciplinary devices. Higher employment protection makes these devices more costly, and employers dismiss less often. Thereby, the value of jobs for shirkers increases in efficiency wage models. In this situation, the employer might raise monitoring in

\footnotetext{
${ }^{7}$ Perceived job security might decrease, too. For the positive relation between perceived job security and life satisfaction in economics, see: Praag, Frijters, and Ferrer-i-Carbonell (2003), Geishecker (2012), Green (2011), Campbell, Carruth, Dickerson, and Green (2007). For the relation between job security and life satisfaction in psychology, see: Cheng and Chan (2008), De Witte (2005) and Sverke, Hellgren, and Näswall (2002).

${ }^{8}$ For recent controversial discussion on this "paradox", see Easterlin, McVey, Switek, Sawangfa, and Zweig (2010) and Stevenson and Wolfers (2008).
} 
order to avoid shirking. A decrease in EPLP, therefore, might decrease monitoring, and hence, stress. ${ }^{9}$ Indeed, Lepage-Saucier and Wasmer (2012) show that EPLP is positively related with stress. Hence, permanent workers might benefit in terms of well-being: monitoring hypothesis.

\subsection{Employability as a loss multiplier?}

Previous research shows that perceived employability is an important mediator of the effect of unemployment and perceived job insecurity on well-being (Green, 2011). Individuals who perceive themselves as less employable - measured as low expectations to find a good job - suffer more from unemployment and perceived job insecurity. Psychologist explain this by the degree of perceived dependency on the current job, which is higher when perceived employability is low.

In this study, I explore whether changes in EPLP affect workers differently depending on their perceived employability. For instance, temporary workers who perceive their employability as low might have much stronger preferences for a permanent job than others because they expect to face major difficulties in finding a new job. Hence, when they do not manage to transition, even though the propensity to do so increased, they could suffer even stronger when comparing to colleagues who transitioned. The same applies to permanent workers.

\section{Institutional background}

\subsection{Employment protection in Germany}

In international comparison, Germany's dismissal protection for permanent contracts ranked among the top five of OECD countries in 2013 (Venn, 2009; OECD, 2015). Hence, it ranks similarly to Portugal and France, but much higher compared to United Kingdom and United States. German EPLP is regulated in the Protection Against Dismissal Act, in the Civil Code, and in laws for specific groups such as disabled workers. The latter two regulations apply to all firms and define minimum criteria for a fair dismissal (e.g. written form, specific period of notification, and application of good faith, basic rights). In the case of an unfair dismissal, the court decides over severance payments.

\footnotetext{
${ }^{9}$ Furthermore, less monitoring (personal control) is positively related to job satisfaction (Warr, 2003). For the relation between job satisfaction and life satisfaction in economics, see (Praag, Frijters, and Ferrer-i-Carbonell, 2003). For the effect of job satisfaction on life satisfaction in psychology, see Warr (2003), Iverson and Maguire (2000) and Judge and Locke (1993).
} 
The Protection Against Dismissal Act, in contrast, only applies to firms that pass a threshold in terms of the number of employees and defines stricter rules which have to be met for a fair dismissal. Dismissals are only considered fair under EPLP regulations if: 1) the cause lies in the worker (e.g. long-term incapacity), 2) the worker's behavior is deemed damaging or unacceptable (e.g. theft), or 3) it is an economic necessity. A dismissed worker has the right to bring the case to court but only if s/he did not forgo this right by accepting severance payments. In case of an unfair dismissal, the worker has the right to return to the firm or to claim severance payments. Hence, the Protection Against Dismissal Act increases adjustment costs in terms of transfers, e.g. severance payments, and taxes, e.g. procedural costs of dismissals, only for firms above a specific threshold. In the following, I refer to this German legislation as EPLP.

\subsection{Reforms in employment protection}

This paper investigates variation in EPLP across firm size (threshold regulation) and variation across time (reforms in 1996 and 1999). Figure 1 shows which firms depending on firm size size [measured in full time equivalent employees (FTE)] are required to meet regulations of the EPLP between 1995 and 2000. Before the reform in 1996, all workers in firms with more than 5 FTE were covered by the EPLP. The Christian Democrat/Liberal government decided on reforms in order to increase the flexibility of the labor market. On the 1st of October in 1996, the minimal number of FTE was increased from 5 to 10 FTE for newly hired permanent workers, i.e. contracts were signed after the 30th of September in $1996 .{ }^{10}$ This means that small firms with less than 10 FTE did not have to apply the EPLP for newly hired permanent workers anymore. From this date on, newly hired permanent workers in small firms could be dismissed much more easily. Incumbents who signed the permanent contract before the reform took place (1st of October in 1996), however, were exempted from the reform until September 1999. For these workers only a decrease in future EPLP (September in 1999) became effective on the 1st of October in 1996. Thereby, incumbent permanent workers faced no direct change in EPLP on the reform date.

The second reform took place on the 1st of January in 1999. In this reform, the Social Democrat/Green government re-regulated the law and returned to the

\footnotetext{
${ }^{10}$ Social selection criteria in the case of economic redundancies were loosened. The FTE calculation changed.
} 
old threshold. ${ }^{11}$ Thereby, newly hired permanent workers, i.e. whose contracts were signed after the 30th of September 1996, who were employed in firms with 6 to 10 FTE faced an increase in employment protection on the 1st of January in 1999. Incumbent workers, i.e. whose contracts were signed before the 1st October in 1996, the reform in 1996 did not change EPLP. Only incumbents who signed the contract after September in 1996 faced an increase in EPLP. According to OECD (2015), the share of workers with a job tenure more than three years in total employment was 27.9 percent in 1999. Including temporary and permanent workers, however, this figure indicates that only a small share of permanent workers were affected by the increase in EPLP. Therefore, the policy effects for permanent workers should be understood as a lower bound estimates. The 1999 reform took place after elections in September 1998, in which this reform was already strongly discussed (Bauer, Bender, and Bonin, 2007). Therefore, I discuss anticipation of the reform in the empirical analyses (Section 5).

Finally, for identification issues, it is important whether parallel reforms took place. On the 1st of October in 1996, the regulation of fixed-term work was liberalized (increasing the maximum duration from 18 to 24 months and allowing renewals up to three times). ${ }^{12}$ These reforms, however, apply to all firms and workers.

\section{Empirical strategy}

\subsection{Identification strategy}

The effect of EPLP on well-being is identified by exploiting variable enforcement across firm-size and within-country time variation of EPLP (Boeri and Jimeno, 2005). Employing these kinds of variations in a difference-in-difference approach became a standard tool for causality analyzes of the effect of EPL reforms on objective outcomes (e.g. Leonardi and Pica, 2013; Martins, 2009; Kugler and Pica, 2008; Bauer, Bender, and Bonin, 2007; Boeri and Jimeno, 2005).

The threshold regulation reforms in 1996 and 1999 in Germany serve as quasiexperiments. These reforms in German EPLP were already evaluated in their effects on, for instance, employment dynamics (Bauer, Bender, and Bonin, 2007), job duration (Boockmann, Gutknecht, and Steffes, 2008), temporary employment (Boockmann and Hagen, 2001). Figure 1 shows that the reforms generated a subgroup of

\footnotetext{
${ }^{11}$ The FTE calculation changed slightly and the selection criteria were strengthened.

${ }^{12}$ Furthermore, in 1997 temporary agency work was liberalized and in 2001 fixed-term work as well as temporary agency work was liberalized.
} 
Figure 1: EPLP reforms in Germany from 1996 to 2005

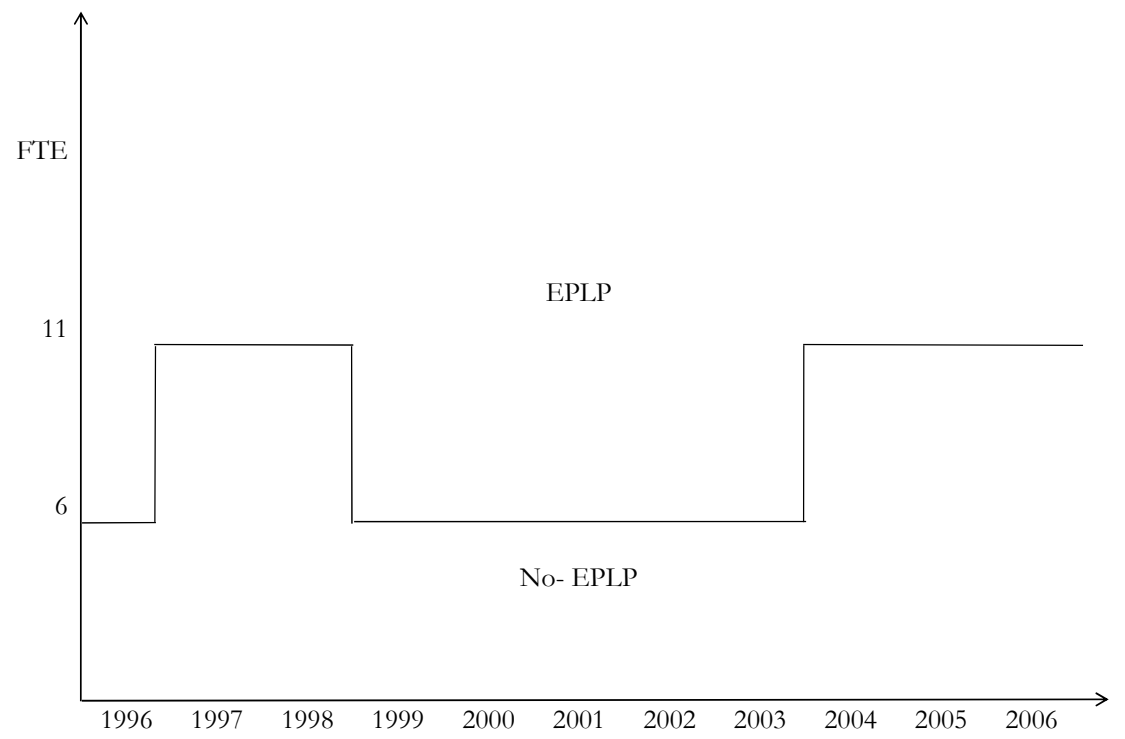

Note: Own presentation; FTE: full-time equivalent workers; EPLP: employment protection legislation for permanent workers. 
firms which faced a change in EPLP and a subgroup of firms, for whom EPLP did not change. Workers who are employed in firms with 6-10 FTE are defined to be treated (the treatment group), while workers in firms above 10 FTE serve as controls (the control group). I compare the change in well-being for the treatment group to that of the control group. The difference-in-difference estimator is the effect of EPLP on well-being if the identifying assumption of a common trend is true.

The effect of EPLP is estimated by the following empirical specification:

$$
\begin{gathered}
Y_{i t}=\gamma_{1} T G_{i}+\gamma_{2} T G_{i} R_{t}+\gamma_{3} R_{t}+\boldsymbol{\beta}^{\prime} \boldsymbol{X}_{i t}+\epsilon_{i t} \\
R_{t}=1\left[\text { year } \geq \text { reform year } r_{t}\right] \\
\epsilon_{i t}=u_{i t}+a_{i}
\end{gathered}
$$

$Y_{i t}$ is the dependent variable which is measured at the level of individual $i$ in time $t, T G_{i}$ is the dummy for being in the treatment group or not, $R_{t}$ is the reform dummy, $\mathbf{X}_{i t}$ represents a vector of covariates and $\epsilon_{i t}$ is the error term. $\mathbf{X}_{i t}$ contains determinants which are important for well-being equations with well-being proxied by life satisfaction. In the baseline model, $T G_{i}$ is time-invariant. It equals one if an individual works in a small firm at the time of the reform and zero if an individual works in a large firm $\left(T G_{i}\right) .{ }^{13} T G_{i}$ captures group specific time-invariant differences between the treatment and the control group which are not linked to the reform. The coefficient of the interaction between the reform dummy $\left(R_{t}\right)$ and the treatment group dummy $\left(T G_{i}\right)$ is the main measure of interest: the policy effect $\left(\gamma_{2}\right)$.

In order to check whether there are pre-treatment trend differences and whether the policy effect fades or grows, I add pre-reform and post-reform policy effects similar to Autor (2003). The additional included reform dummies are coded as follows

$$
\begin{aligned}
& R_{t-1}=1\left[\text { year } \geq \text { reform } \text { year }_{t-1}\right] \\
& R_{t+1}=1\left[\text { year } \geq \text { reform year } \text { y }_{t+1}\right]
\end{aligned}
$$

The error term $\epsilon_{i t}$ contains a time-invariant individual fixed effect $a_{i}$ and an idiosyncratic component $u_{i t}$. Individual fixed effects are very important for well-being equations since time-invariant personality traits have a large effect on well-being (Ferrer-i-Carbonell and Frijters, 2004). It is assumed that $Y_{i t}$ is cardinal. According to Ferrer-i-Carbonell and Frijters (2004), the cardinality versus ordinality assump-

\footnotetext{
${ }^{13}$ In other specifications, $T G_{i}$ is time-variant and equals one if an employee works in a small firm in the year of observation but zero otherwise $\left(T G_{i t}\right)$.
} 
tion is relatively unimportant for well-being measured as life satisfaction on a 0 to 10 scale. ${ }^{14}$ I estimate a variance-covariance matrix, which accounts for the possible correlation of the errors at the individual-level as well as for heteroscedasticity.

The identifying assumption for DID analyzes is the common trend assumption. The treatment and control group are allowed to differ in terms of the outcome, but this difference is not allowed to change over time. The assumption fails if the composition of treatment and control group change, if groups differ in their time varying covariates, or if a constantly different composition induces diverging dynamics in the outcome. For instance, after a decrease in protection in small firms, workers with children who prefer protected jobs could sort into bigger firms. In order to tackle these issues, observable differences and time-invariant unobservable differences are controlled for by including $\mathbf{X}_{i t}$ and estimating fixed-effects. Important covariates are, e.g., age, age square, income, and children. Thereby, I generalize the common trend assumption: conditional on mentioned controls, the treatment and control group are assumed to have a the same trend in the dependent variable. Time-variant unobserved heterogeneity, however, is not controlled for. To assess the plausibility of the common trend assumption, I run placebo reform tests, placebo group tests, and pre-reform tests. For life satisfaction, the tests support the common trend and are discussed in Section $5 .^{15}$

\subsection{Data}

The data source is the German Socio-Economic Panel (GSOEP). The GSOEP is a representative survey of currently more than 11,000 private households and 20,000 individuals in Germany. The first wave was conducted in 1984 and has been repeated annually since then. Haisken-DeNew and Frick (2005) present technical details. The major advantage of the GSOEP for well-being equations is its longitudinal structure. The major disadvantage of the GSOEP for this study is that the treatment group variable is associated with measurement error (discussed below). This biases the effect towards zero.

\section{Variables}

The dependent variable of interest is well-being $\left(Y_{i t}\right)$. Well-being is proxied by overall life satisfaction, which is a retrospective evaluation of life (Kahneman and Krueger,

\footnotetext{
${ }^{14}$ The authors compare fixed effect ordered logit models, ordered logit and fixed effect OLS.

${ }^{15}$ See Appendix B.
} 
2006). ${ }^{16}$ The GSOEP contains the standard single-item life satisfaction question (Kahneman and Krueger, 2006), "How satisfied are you with your life, all things considered? Completely dissatisfied (0) - completely satisfied (10)." With regard to the statistical quality, this single-item life satisfaction question is considered to be a reliable and valid measure in several studies. One of the most recent reviews of this literature is given in OECD (2013) and in Clark, Diener, Georgellis, and Lucas (2008). ${ }^{17}$ Of course, limitations have to be taken into account (OECD, 2013), e.g. occasion-specific events, and placement in the survey.

Concerning the contract type of a worker, I define permanent workers as workers holding an unlimited contract, while temporary workers are defined as workers holding a limited contract. The temporary workers are either temporary agency workers - workers who signed a contract with a private employment agency and were hired by third party firms - or workers with a fixed-term contract who were directly hired by the firm. Before 1995, the GSOEP contains only insufficient information on contract types.

In accordance to Green (2011), I proxy employability by the perceived easiness of finding a new job. ${ }^{18}$ Workers are defined to perceive their employability as low if they answered that it would be difficult or practically impossible to find a comparable new job. This variable is available for 1997 and 1999.

I also include several control variables $\left(\mathbf{X}_{i t}\right)$ which are important for well-being equations and usually included in such estimations (e.g. Kassenboehmer and HaiskenDeNew, 2009; Clark and Senik, 2010): household net income, working hours, age,

\footnotetext{
${ }^{16}$ In the economic literature, well-being proxied as life satisfaction is usually linked to the concept of utility (Kahneman and Krueger, 2006). It is distinguished between expected (decision) utility (Clark, Diener, Georgellis, and Lucas, 2008; Benjamin, Heffetz, Kimball, and Rees-Jones, 2012), experienced utility (Kahneman and Krueger, 2006; OECD, 2013), and remembered utility (Kahneman and Krueger, 2006). The latter is a weighted average of experienced utility. Life satisfaction is considered as remembered utility (Kahneman and Krueger, 2006). With respect to the relation between life satisfaction and expected utility, expected utility is not necessarily equal to remembered utility as individuals make systematic computational mistakes, e.g. by neglecting adaptation (Clark, Diener, Georgellis, and Lucas, 2008). Even if individuals would not make computational mistakes with regard to the consequences of their choices for utility, they would not solely maximize life satisfaction (remembered utility) but would consider other aspects (Benjamin, Heffetz, Kimball, and Rees-Jones, 2012; Clark, Diener, Georgellis, and Lucas, 2008).

${ }^{17}$ OECD (2013) and Clark, Diener, Georgellis, and Lucas (2008) present literature on the facts that life satisfaction is correlated with real phenomena such as brain activity and smiling, that third party evaluation correlates the respondent's own report, that satisfaction measures have objective consequences (Oswald, Proto, and Sgroi, 2013; Krause, 2013), and that life satisfaction has robust relationships with, e.g. health, income, and unemployment (e.g. Kassenboehmer and Haisken-DeNew, 2009; Luttmer, 2005).

${ }^{18}$ The GSOEP question is: "If you were to lose your job, would it be easy, difficult, or practically impossible for you to find a comparable job?". Outcomes are: "easy (1), difficult (2) or practically impossible (3)".
} 
education, female dummy, whether children live in the household, year (linear trend), state dummies (regional labor market effects), and year fixed effects (year specific macro effects).

\section{Treatment Group Dummy}

The treatment group is defined via the number of FTEs. Figure 1 shows that workers in firms with 6 to 10 FTEs versus workers in firms above 10 FTEs should be identified. ${ }^{19}$ In the EPLP, FTEs are measured by subtracting the number of workers in training from the overall number of employees and weighting the part-time workers by a specific key.

A major drawback of the GSOEP is that FTEs cannot be measured precisely. The GSOEP asks, " Approximately how many people does the company employ as a whole?" [less than 5, 5-19, 20-199 (99, 100-199 after the year 1998), 200-1999, at least 2000 workers, self-employed without coworkers]. Workers who answered that they were in firms with 5-19 (20-199) workers are defined as the treatment (control) group. Thereby, the treatment group probably includes workers who were not treated. At the same time, the control group might include workers who were actually treated. Hence, the policy effect is likely to be biased towards zero, and the true effects of EPLP are stronger.

I define two different treatment group dummies. First, for the time-invariant treatment group dummy $\left(T G_{i}\right)$ the treatment status is measured at the time of the last interview before the reform takes place. The dummy is defined to be one, if the worker is employed in a firm with 5-19 employees at the time of the reform, and defined to be zero, if s/he works in a firm with 20-199 employees. The treatment status does not change over time, even if the number of workers in the firm changes. Second, the time-variant treatment group dummy $\left(T G_{i t}\right)$ is measured at the year of observation. It is one, if the worker is employed in a firm with 5-19 employees in the year of observation, and zero, if s/he works in a firm with 20-199 employees in the year of observation. The treatment status is allowed to change. In the latter case, workers might enter or exit the sample due to changes in the number of workers in the firm. The advantage of the time-variant treatment group dummy is that the number of observations are higher, which is important in order to study effect heterogeneity.

\footnotetext{
${ }^{19}$ I choose larger firms as the control group, because Bauer, Bender, and Bonin (2007) show that smaller firms face different dynamics with regard to insolvencies.
} 


\subsection{Sample selection and descriptive statistics}

I construct separate samples for temporary and for permanent workers as well as for both reforms. The samples are restricted to employees who are employed in private firms, between 15 and 65 years old, without missing values in questions on job security as well as on job satisfaction. ${ }^{20}$ Further, I exclude employees who are in the upper/lower 1st income percentile. Concerning the reform periods, I start observing individuals around two years before and two years after the reform. Therefore, for the 1996 reform, the sample period begins in 1995 and ends in $1998 .{ }^{21}$ For the 1999 reform, I start in 1997 and end in 2001. It is not possible to start earlier because of the 1996 reform. Finally, the samples are restricted to workers for whom the treatment group dummy is defined.

Concerning permanent workers, the sample includes newly hired permanent workers who face an actual change in EPLP and incumbent workers who face only the announcement of a change in EPLP. This biases the effect of a direct change in EPLP towards zero. As the sample becomes very small, however, when it is restricted to newly hired workers, the main analyzes are conducted for the full sample of permanent workers. ${ }^{22}$ Furthermore, the sample for permanent workers excludes workers in the probationary period as here EPLP does not apply.

Samples for each contract type (permanent workers, temporary workers) and for each reform period (1995 until 1998, 1998 until 2001) are generated:

(i). Sample A - workers irrespective of their employment status after the reform: The effect of a change in EPLP on workers who were in a temporary or in a permanent contract at the time of the reform is analyzed. For this purpose, I construct a sample of temporary/permanent workers who were, at the time of their last interview prior to the reform, in a temporary/permanent contract as well as employed in private firms with 5-199 workers. The treatment group is time-invariant $\left(T G_{i}\right)$. For instance, if person $\mathrm{A}$ is in a temporary job in a firm with 20-199 employees in 1996, prior to the reform, but in a permanent job in 1997, the person is included in the sample of temporary workers but not in the sample of permanent workers. I allow the panel to be unbalanced.

\footnotetext{
${ }^{20}$ Results for life satisfaction as the dependent variable are relatively robust to this restriction. See Appendix E for Sample B. Sample is restricted due to models which investigate job security and job satisfaction as the dependent variables. See Appendix B.

${ }^{21}$ Results for Sample B are robust to this restriction and are robust to the ending month in 1998. See Section 5.3.

${ }^{22}$ For results when I focus on newly hired workers, see Appendix D.
} 
(ii). Sample B - workers remain in the employment status after the reform: I investigate the effect of a change in EPLP on workers when they remain in their contract type (e.g. remain temporary workers) after the reform. For this purpose, I construct a sample which includes only persons who are observed in the specific year in a temporary/permanent contract and stay either in the control or treatment group (stayers). ${ }^{23} \mathrm{I}$ allow the treatment group to vary over time $\left(T G_{i t}\right){ }^{24}$ For instance, if person A holds a temporary contract in a firm with 5-19 employees in 1995, 1996, and 1997 but not in 1998, I keep three observations (1995-1997) in the sample of temporary workers. I allow the panel to be unbalanced.

Tables 1 and 2 present descriptive statistics of the Sample A for temporary and permanent workers. ${ }^{25}$ Temporary workers are usually younger than permanent workers because temporary contracts are often used to screen the productivity of younger workers or to train youth in dual apprenticeships. This is also the case in the estimation samples. On average, temporary workers are around 30 years old, whereas permanent workers are, on average, around 40 years old. In terms of monthly household net income, permanent workers are better off compared to temporary workers. Life satisfaction and job satisfaction is around 7 on a scale of 0 to 10 for temporary and permanent workers.

\section{Empirical results}

The main result is that, on average, temporary workers suffered temporarily in terms of life satisfaction from the decrease in EPLP in $1996 .{ }^{26}$ The negative effect of the decrease in EPLP on life satisfaction of temporary workers is specifically strong for temporary workers who remain in a temporary job after the reform. This could be explained by social comparison. Furthermore, less employable workers are specifically strong affected. The decrease in EPLP had no significant effect on wellbeing, which would be in line with loss aversion. As the EPLP reforms affected newly

\footnotetext{
${ }^{23}$ For robustness checks for samples including movers, i.e. workers who are allowed to switch between treatment and control group, see Section 5.3.

${ }^{24}$ Alternatively, I could estimate the effect based on a subsample of Sample A. As I run out of observations in that case, I stick to Sample B.

${ }^{25}$ For descriptive statistics of Sample B, see Appendix A.

${ }^{26}$ Results with longitudinal weights change in the sense that the signs of the policy effects remain similar but that standard errors become larger. Among others, however, this is due to the use of the fixed-effect dummy estimator and not the mean difference estimator, which is used for the presented results.
} 
Table 1: Descriptive statistics: temporary workers (at the date of the reform)

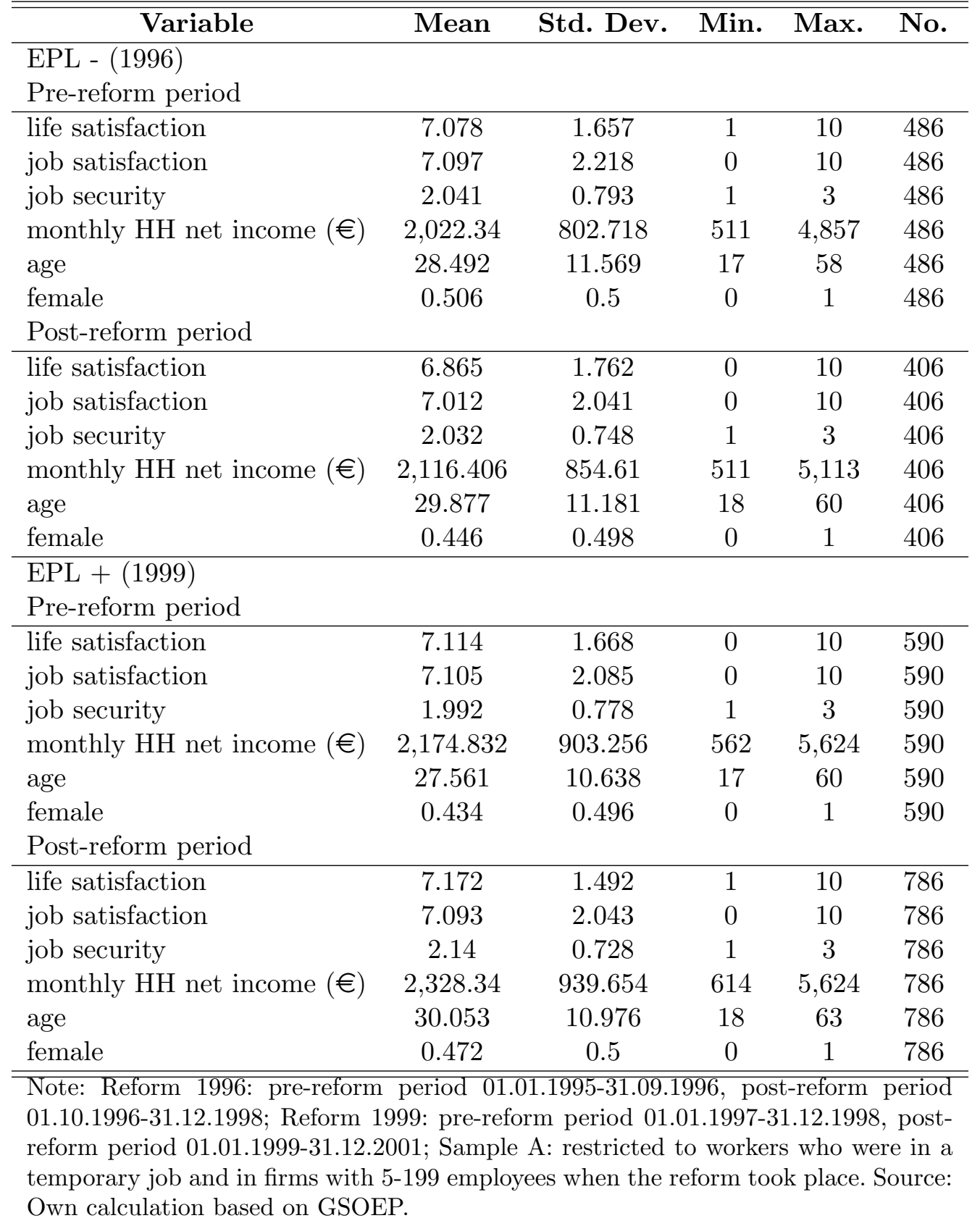


Table 2: Descriptive statistics: permanent workers (at the date of the reform)

\begin{tabular}{|c|c|c|c|c|c|}
\hline Variable & Mean & Std. Dev. & Min. & Max. & No. \\
\hline \multicolumn{6}{|l|}{ EPL - (1996) } \\
\hline \multicolumn{6}{|l|}{ Pre-reform period } \\
\hline life satisfaction & 7.039 & 1.583 & 0 & 10 & 3,634 \\
\hline job satisfaction & 7.025 & 1.995 & 0 & 10 & 3,634 \\
\hline job security & 2.325 & 0.696 & 1 & 3 & 3,634 \\
\hline monthly HH net income $(€)$ & $2,202.242$ & 819.236 & 767 & 5,778 & 3,634 \\
\hline age & 39.547 & 10.57 & 17 & 65 & 3634 \\
\hline female & 0.424 & 0.494 & 0 & 1 & 3634 \\
\hline \multicolumn{6}{|l|}{ Post-reform period } \\
\hline life satisfaction & 6.953 & 1.58 & 0 & 10 & 3,325 \\
\hline job satisfaction & 6.916 & 1.943 & 0 & 10 & 3,325 \\
\hline job security & 2.194 & 0.707 & 1 & 3 & 3,325 \\
\hline monthly HH net income $(€)$ & $2,277.961$ & 835.237 & 767 & 5,783 & 3,325 \\
\hline age & 40.879 & 10.194 & 18 & 65 & 3,325 \\
\hline female & 0.428 & 0.495 & 0 & 1 & 3,325 \\
\hline \multicolumn{6}{|l|}{$\mathrm{EPL}+(1999)$} \\
\hline \multicolumn{6}{|l|}{ Pre-reform period } \\
\hline life satisfaction & 7.018 & 1.558 & 0 & 10 & 3,818 \\
\hline job satisfaction & 6.976 & 1.924 & 0 & 10 & 3,818 \\
\hline job security & 2.191 & 0.714 & 1 & 3 & 3818 \\
\hline monthly HH net income $(€)$ & $2,260.053$ & 825.903 & 818 & 5,624 & 3,818 \\
\hline age & 40.018 & 10.186 & 18 & 65 & 3,818 \\
\hline female & 0.429 & 0.495 & 0 & 1 & 3,818 \\
\hline \multicolumn{6}{|l|}{ Post-reform period } \\
\hline life satisfaction & 7.068 & 1.553 & 0 & 10 & 5,191 \\
\hline job satisfaction & 6.902 & 1.913 & 0 & 10 & 5,191 \\
\hline job security & 2.263 & 0.688 & 1 & 3 & 5,191 \\
\hline monthly HH net income $(€)$ & $2,380.785$ & 836.193 & 818 & 5,624 & 5,191 \\
\hline age & 41.872 & 9.773 & 20 & 65 & 5,191 \\
\hline female & 0.432 & 0.495 & 0 & 1 & 5,191 \\
\hline $\begin{array}{l}\text { Note: Reform 1996: pre-reform } \\
01.10 .1996-31.12 .1998 ; \text { Reform } \\
\text { reform period 01.01.1999-31.12. } \\
\text { permanent job and in firms with } \\
\text { Own calculation based on GSOI }\end{array}$ & eriod 01 & $\overline{1995-31.09}$ & $96, \mathrm{pc}$ & reform & $\begin{array}{l}\text { period } \\
\text { post- } \\
\text { e in a } \\
\text { ource: }\end{array}$ \\
\hline
\end{tabular}


hired workers but almost not incumbents, a large proportion of permanent workers were not affected from the decrease and increase in EPLP. Hence, as I expected, I did not find any effects of the reforms on their well-being. Importantly, however, all results should be considered as lower bound estimates due to a non-negligible measurement error in the treatment status. The true effects might be stronger.

\section{Common trend assumption}

Before I present the results, the common trend assumption is discussed. The common trend assumption is the identifying assumption for the unbiasedness of the policy effect in a DID approach. Although no formal test exists in order to assess the validity of this, pre-treatment trend and placebo tests help to assess whether the assumption is critical. I summarize the main findings here, before I present the results.

Pre-treatment tests do not confirm any significant pre-treatment differences in life satisfaction as the dependent variable controlling for observable and timeinvariant unobservable heterogeneity. ${ }^{27}$ In Tables 3, 4, and 5, I test whether a common pre-policy trend for the treatment and the control group is rejected TGxReform(t-1). None of the coefficients, however, is significant. ${ }^{28}$ Hence, in the pre-treatment period, I capture all the relevant heterogeneity which might induce different trends between treatment and control group in terms of life satisfaction. This shows that unobserved time-variant heterogeneity does not yield a different trend between treatment and control group in life satisfaction in the pre-reform period. This finding might at least reduce concerns about the relevance of unobserved time-variant heterogeneity for the policy effects, even though some concerns remain due to an unbalanced sample.

Placebo tests for Sample B show that life satisfaction did not change for workers in medium sized (non-treated) versus large firms (non-treated) at the time of the reforms (placebo group test); and it did not change for workers in the treatment group (small sized firms) versus workers in the control group (medium sized firms) in 1998 (placebo reform). ${ }^{29}$ Overall, I do not find evidence against the hypothesis that treatment and control group follow a common trend for life satisfaction.

\footnotetext{
${ }^{27}$ I also tested pre-treatment trend differences for perceived job security and job satisfaction. As I observe pre-treatment differences, which I cannot explain by anticipation, I do not consider them as dependent variables in this study. See Appendix B.

${ }^{28}$ Additional checks for Sample B support this (Appendix B).

${ }^{29}$ See Appendix B.
} 


\subsection{Effect of EPLP on life satisfaction}

This section tests for the effect of EPLP reforms on life satisfaction of workers who were either temporarily or permanently employed at the time of the reform (Sample A). These workers are allowed to change their employment status after the reform, e.g. from a temporary to a permanent job.

\section{Temporary workers}

The theoretically expected effect of a decrease in EPLP on the well-being of workers who were in a temporary job at the time of the reform is ambiguous. The transition hypothesis expects a positive effect, while the comparison and anticipation hypotheses suggest a negative effect on well-being.

The DID results for the 1996 reform with life satisfaction as the dependent variable is presented in the upper left part of Table 3. The main result is that workers who were in a temporary job at the time of the reform suffered by around 0.5 units in life satisfaction (TGxReform) from the decrease in EPLP in 1996 - see columns (1) to (3). Thus, the transition hypothesis is outweighed by the comparison and anticipation hypotheses. The preferred model with unobservable and observable heterogeneity is presented in column (3). In this specification, temporary workers loose 0.407 units of life satisfaction due to a decrease in EPLP which is $5.8 \%$ of the mean. When I exclude the socio-demographic control variables, the policy effect becomes larger in its magnitude (-0.548). This could be due to observables, which capture different dynamics between control and treatment group. The results for the 1999 reform are presented in the right part of Table 3 - see columns (4) to (6). The increase in EPLP had no significant effect on life satisfaction. It is possible that this is due to effect heterogeneity, which is investigated in Section 5.2.

\section{Permanent workers}

Theoretical expectations for the effect of a decrease in EPLP on the life satisfaction of permanent workers are ambiguous, too. While the insecurity hypothesis suggests a negative effect, the monitoring hypothesis expects a positive one. Due to the reform design, however, I do not expect strong effects of the reforms on life satisfaction of permanent workers.

The lower part of Table 3 shows the results for the reform in 1996 (decreasing EPLP) - see columns (1) to (3) - and for the reform in 1999 (increasing EPLP) see columns (4) to (6). The policy effects (TGxReform) are not different from zero 
Table 3: Dependent variable: life satisfaction

\begin{tabular}{|c|c|c|c|c|c|c|}
\hline & \multicolumn{3}{|c|}{ EPL - (1996) } & \multicolumn{3}{|c|}{$\mathrm{EPL}+(1999)$} \\
\hline & (1) & $(2)$ & (3) & $(4)$ & $(5)$ & $(6)$ \\
\hline & \multicolumn{6}{|c|}{ Temporary workers (at the date of the reform) } \\
\hline & FE & FE & FE & FE & $\mathrm{FE}$ & FE \\
\hline TGxReform(t-1) & & $\begin{array}{l}-0.154 \\
(0.232)\end{array}$ & $\begin{array}{l}-0.185 \\
(0.244)\end{array}$ & & $\begin{array}{c}0.140 \\
(0.210)\end{array}$ & $\begin{array}{l}0.0882 \\
(0.220)\end{array}$ \\
\hline TGxReform & $\begin{array}{l}-0.395^{*} \\
(0.202)\end{array}$ & $\begin{array}{c}-0.548^{* *} \\
(0.221)\end{array}$ & $\begin{array}{c}-0.407^{*} \\
(0.236)\end{array}$ & $\begin{array}{c}-0.00717 \\
(0.160)\end{array}$ & $\begin{array}{r}-0.0686 \\
(0.189)\end{array}$ & $\begin{array}{r}-0.0179 \\
(0.192)\end{array}$ \\
\hline TGxReform $(\mathrm{t}+1)$ & & $\begin{array}{l}0.463^{*} \\
(0.259)\end{array}$ & $\begin{array}{c}0.415 \\
(0.259)\end{array}$ & & $\begin{array}{l}0.0292 \\
(0.173)\end{array}$ & $\begin{array}{c}0.167 \\
(0.180)\end{array}$ \\
\hline Socio-demo. controls & no & no & yes & no & no & yes \\
\hline$N$ & 892 & 892 & 892 & 1,376 & 1,376 & 1,376 \\
\hline \multirow[t]{3}{*}{$R^{2}$} & 0.023 & 0.029 & 0.091 & 0.011 & 0.011 & 0.050 \\
\hline & \multicolumn{6}{|c|}{ Permanent workers (at the date of the reform) } \\
\hline & $\mathrm{FE}$ & $\mathrm{FE}$ & FE & FE & FE & $\mathrm{FE}$ \\
\hline TGxReform(t-1) & & $\begin{array}{l}0.0336 \\
(0.074)\end{array}$ & $\begin{array}{l}0.0499 \\
(0.074)\end{array}$ & & $\begin{array}{l}0.0397 \\
(0.071)\end{array}$ & $\begin{array}{l}0.0683 \\
(0.073)\end{array}$ \\
\hline TGxReform & $\begin{array}{r}-0.0370 \\
(0.061)\end{array}$ & $\begin{array}{c}-0.0988 \\
(0.075)\end{array}$ & $\begin{array}{r}-0.0622 \\
(0.078)\end{array}$ & $\begin{array}{l}0.0322 \\
(0.052)\end{array}$ & $\begin{array}{c}-0.00483 \\
(0.069)\end{array}$ & $\begin{array}{c}0.00165 \\
(0.069)\end{array}$ \\
\hline TGxReform $(t+1)$ & & $\begin{array}{c}0.100 \\
(0.076)\end{array}$ & $\begin{array}{l}0.0917 \\
(0.075)\end{array}$ & & $\begin{array}{l}0.0324 \\
(0.067)\end{array}$ & $\begin{array}{l}0.0183 \\
(0.071)\end{array}$ \\
\hline Socio-demo. controls & no & no & yes & no & no & yes \\
\hline$N$ & 6,959 & 6,959 & 6,959 & 9,009 & 9,009 & 9,009 \\
\hline$R^{2}$ & 0.007 & 0.007 & 0.025 & 0.002 & 0.002 & 0.014 \\
\hline $\begin{array}{l}\text { Note: Fixed effects }(\mathrm{FE} \\
{ }^{* *} p<0.05,{ }^{* * *} p<0 .( \\
\text { reform year] } ; \text { Reform }(\mathrm{t}- \\
=[1 \text { if year }>=\text { one ye } \\
\text { in a permanent/tempol } \\
199 \text { employees at the ti } \\
\text { Socio-demographic (soc } \\
\text { working hours, working } \\
\text { state fixed effects. }\end{array}$ & $\begin{array}{l}\text { estimati } \\
1 ; \mathrm{TG}= \\
=[1 \text { if } \\
\text { ar after t } \\
\text { ary job a } \\
\text { ne of the } \\
\text { o-demo.) } \\
\text { hours }{ }^{2} \text {, ag }\end{array}$ & $\begin{array}{l}\text { s, cluster } \\
\text { if } 5-19 \text { ar } \\
\text { ear > }>0 \\
\text { reform } \\
\text { the time } \\
\text { form; Cor } \\
\text { ontrols: fi } \\
\text { age }^{2} \text {, edu }\end{array}$ & $\begin{array}{l}\text { d standar } \\
\text { l TG }=0 \\
\text { e year bef } \\
\text { ar]; Samp } \\
\text { f the refo } \\
\text { rols: refor } \\
\text { n size dur } \\
\text { ation, fem }\end{array}$ & $\begin{array}{l}\text { errors in } \\
\text { if } 20-199 ; \\
\text { re the refo } \\
\text { e A: samp } \\
\text { m and em } \\
\text { n dummies } \\
\text { mies, log }\end{array}$ & $\begin{array}{l}\text { arentheses; } \\
\text { eform = [1 } \\
\mathrm{cm} \text { year]; } \mathrm{r} \\
\text { of worke } \\
\text { loyed in fi } \\
\text { TG, year } \\
\text { f monthly }\end{array}$ & $\begin{array}{l}p<0.10, \\
\text { f year }>= \\
\text { form }(t+1) \\
\text { who were } \\
\text { s with } 5- \\
\text { ed effects; } \\
\text { H income, } \\
\text { ies as well }\end{array}$ \\
\hline
\end{tabular}


for both reforms, which is in line that a large proportion of permanent workers were not directly affected by the reforms. Effect heterogeneity, however, might explain the zero effects, too, and is elaborated in Section 5.2.

\subsection{Effect heterogeneity}

Based on the comparison, transition, and insecurity hypotheses, workers who remain in their contract type after the reform might exhibit a different reform effect, on average, compared to workers who transition into another employment status. In order to investigate this heterogeneity, I construct samples with workers who remained in their contract type after the reform (Sample B) ${ }^{30} .{ }^{31}$ Furthermore, I investigate heterogeneity due to differences in the employability of workers.

\section{Temporary workers}

If the comparison hypothesis explains the negative effect of EPLP in 1996 on life satisfaction of temporary workers (column (3) in Table 3), I would expect that the negative effect is specifically strong for temporary workers who remain in a temporary job in a treated firm after the reform. This is because workers who benefited from potentially increased transition probabilities into permanent work by actually moving into a permanent job are excluded. Thereby, the transition hypothesis becomes less relevant, whereas the comparison hypothesis becomes more relevant, while the relevance of the anticipation hypothesis remains similar.

The main result is that temporary workers who remained in a temporary job suffered significantly in economical and statistical terms (TGxReform) in life satisfaction from the decrease in EPLP in 1996 (Table 4). The negative effect of the 1996 reform holds independently of controlling for observed heterogeneity or not and for excluding pre- and post-policy effects - see columns (1) to (3). In the preferred specification, temporary workers suffered by 0.588 units in life satisfaction - see column (3) - which is $8 \%$ of the mean, and thereby, higher as the effect on temporary workers who are allowed to move into a permanent job after the reform $(5.8 \%$ of the mean, see column (3) in Table 3). Hence, given that Centeno and Novo (2012) show that EPLP is negatively related to transition probabilities from temporary work to permanent work and based on the findings here, the comparison hypotheses remains a plausible explanation for the negative effect of EPLP on life satisfaction

\footnotetext{
${ }^{30}$ For summary statistics, see Appendix A.

${ }^{31}$ Unfortunately, I run out of observations in the case of subsamples of Sample A.
} 
of temporary workers. ${ }^{32}$

Concerning the common trend assumption, one might be concerned that an adverse selection drives this result. If selection is due to observable or time-invariant unobservable heterogeneity, however, I control for this. If the selection is due to a different trend in life satisfaction which is not captured by aforementioned heterogeneity, I do not control for this. As already mentioned, however, pre-reform trend tests, show that control and treatment group do not differ in their life satisfaction trend in the pre-reform period controlling for above mentioned heterogeneity. This might at least reduce concerns about the relevance of unobserved time-variant heterogeneity for the negative policy effect, even though some concerns remain due to the unbalanced sample.

After one year - see TGxReform(t+1), life satisfaction significantly increases again which is shown in column (3). This is in line with the adaptation to life events. Concerning the increase in EPLP in 1999, I do not find that the unconditional or conditional policy effects (TGxReform) on life satisfaction are different from zero. One might expect that life satisfaction would increase from this reform, however, the results are in line with loss aversion: Workers value a loss stronger compared to a gain.

Finally, the effect of a change in EPLP might also differ with the perceived employability of the workers (Green, 2011). Specifically, highly employable workers might not mind if protection decreases, but less employable workers might be much more concerned. Column (4) of Table 4 presents the results of column (3) for the subsample of workers who gave a valid answer to the question on perceived chances of finding a new job in 1997 (1996 reform) or in 1999 (1999 reform). ${ }^{33}$ Column (5) presents the subsample of less-employable workers, i.e. workers who perceive it to be difficult or practically impossible to find a new comparable job. ${ }^{34}$ Concerning the reform in 1996, the coefficients and standard errors remain quite similar when it is restricted to workers who answered the question on perceived chances to find a new similar job - see columns (3) and (4). Comparing columns (4) and (5), the main result is that the negative effect of the 1996 reform becomes more significant in economical and statistical terms when the sample is restricted to persons who

\footnotetext{
${ }^{32}$ Keeping in mind the measurement error, I test the effect on the transition probabilities, too. I find expected signs but the magnitude and the statistical significance are sensitive. A deeper investigation of this issue remains open for future research.

${ }^{33}$ Subsample estimation instead of interaction terms allows for a higher level of heterogeneity in the life satisfaction equation.

${ }^{34}$ Unfortunately, there are too few workers who feel employable in order to estimate the effects on this subgroup.
} 
feel less employable. They lost 0.703 units in life satisfaction, but this loss is only temporarily. The results for 1999 are presented in the lower part. The policy effect, however, is again statistically not different from zero.

Table 4: Dependent variable: life satisfaction (temporary workers who remain temporary employees)

\begin{tabular}{lccccc}
\hline \hline & $(1)$ & $(2)$ & $(3)$ & $(4)$ & $(5)$ \\
& FE & FE & FE & FE (No MV) & FE (Less Empl) \\
\hline EPL - (1996) & & & & & \\
\hline TGxReform(t-1) & & -0.327 & -0.253 & -0.239 & -0.211 \\
& & $(0.283)$ & $(0.283)$ & $(0.332)$ & $(0.417)$ \\
TGxReform & $-0.543^{*}$ & $-0.595^{*}$ & $-0.588^{*}$ & -0.574 & $-0.703^{*}$ \\
& $(0.311)$ & $(0.342)$ & $(0.342)$ & $(0.348)$ & $(0.417)$ \\
TGxReform(t+1) & & $0.534^{*}$ & $0.553^{*}$ & $0.593^{* *}$ & $0.674^{* *}$ \\
& & $(0.288)$ & $(0.292)$ & $(0.292)$ & $(0.341)$ \\
Socio-demo. controls & no & no & yes & yes & yes \\
\hline$N$ & 624 & 624 & 624 & 540 & 404 \\
$R^{2}$ & 0.040 & 0.053 & 0.110 & 0.133 & 0.172 \\
\hline EPL + (1999) & & & & & \\
\hline TGxReform(t-1) & & 0.106 & 0.148 & 0.0281 & 0.0862 \\
& & $(0.264)$ & $(0.268)$ & $(0.313)$ & $(0.426)$ \\
TGxReform & -0.167 & -0.207 & -0.140 & -0.172 & -0.135 \\
& $(0.238)$ & $(0.263)$ & $(0.271)$ & $(0.273)$ & $(0.326)$ \\
TGxReform(t+1) & & 0.0419 & 0.0802 & 0.0503 & -0.0628 \\
& & $(0.220)$ & $(0.217)$ & $(0.220)$ & $(0.250)$ \\
Socio-demo. controls & no & no & yes & yes & yes \\
\hline$N$ & 1,155 & 1,155 & 1,155 & 757 & 587 \\
$R^{2}$ & 0.008 & 0.008 & 0.047 & 0.063 & 0.069 \\
\hline \hline
\end{tabular}

Note: Fixed effects model (FE), clustered standard errors in parentheses; ${ }^{*} p<0.10,{ }^{* *}$ $p<0.05,{ }^{* * *} p<0.01$; TG $=1$ if $5-19$ and TG $=0$ if 20-199; Reform $=[1$ if year $>=$ reform year]; Reform $(\mathrm{t}-1)=[1$ if year $>=$ one year before the reform year $]$; Reform $(\mathrm{t}+1)=[1$ if year $>=$ one year after the reform year]; Sample B: remain in the contract form (workers who remain in a temporary/permanent job over the sample period), stayers (workers who remain in TG or CG over the sample period); No missing values (No MV): sample of workers with a valid answer to the perception of finding a new job; less employable (less empl): sample of workers who perceive it to be practically impossible or difficult to find a new job; Controls: reform dummies, TG, year fixed effects; Socio-demographic (socio-demo.) controls: log of monthly HH income, working hours, working hours ${ }^{2}$, age, age ${ }^{2}$, education, female, married, child dummies as well state fixed effects.

\section{Permanent workers}

The effect of a decrease in EPLP on permanent workers in sample of workers who remained in a permanent job after the reform is expected to be less negative compared to a sample of workers who might transition into a temporary job or into 
unemployment. This is because permanent workers who suffered from lower EPLP by being dismissed are excluded, and thereby the insecurity hypothesis becomes less relevant. Overall, due to the reform design, however, I do not expect strong effects of both EPLP reforms on the life satisfaction of permanent workers because only newly hired permanent workers faced lower or higher EPLP but a minority of incumbents. ${ }^{35}$ Keeping in mind the bias towards zero due to the measurement error in the treatment status, the upper and lower parts of Table 5 show that the policy effects (TGxReform) are not different from zero - neither for the decrease nor for the increase in EPLP - see columns (1) to (3). The zero effects can also not be explained by effect heterogeneity due to employability - see columns (3) versus (4).

\subsection{Robustness}

\section{Movers and stayers}

Results for Sample B (workers who remain temporary/permanent employed) are restricted to stayers. Stayers are not allowed to switch between small-sized and medium-sized firms, while movers are. Enlarging Sample B of temporary workers to movers, the 1996 policy coefficient in Table 4 changes slightly towards zero. ${ }^{36}$

There are two explanations. First, it would be plausible that stayers compare stronger to their temporarily employed colleagues than movers, and therefore, they are affected stronger by comparing themselves to colleagues who benefited from the EPLP reforms while they did not. Second, the policy effect (TGxReform) is not only identified via a change in legislation but also via job switches. Job switchers, who consciously switch their jobs, face a "honeymoon" and then a "hangover" in terms of satisfaction (Chadi and Hetschko, 2014). If workers are aware of higher transition probabilities in small firms, they might consciously switch. Hence, counteracting the dynamics of the 1996 reform. The finding that from 1995 to the next period of observation a smaller share of workers (2.2\% of workers) switched from a large into a small firm compared to 1996 to the next period $(7.79 \%)$ is in line with this argument (Table 6).

\section{Sample period}

Finally, I test whether the policy effect changes, when I choose different sample periods. Policy effects are estimated for sample periods ending in January and December.

\footnotetext{
${ }^{35}$ In Appendix D, I present results for a sample which is restricted to entries.

${ }^{36}$ See Appendix C, columns (1) to (3) versus (4) to (6) in Table 12.
} 
Table 5: Dependent variable: life satisfaction (permanent workers who remain permanent employees)

\begin{tabular}{|c|c|c|c|c|c|}
\hline & $\begin{array}{l}(1) \\
\text { FE }\end{array}$ & $\begin{array}{l}(2) \\
\mathrm{FE} \\
\end{array}$ & $\begin{array}{l}(3) \\
\mathrm{FE} \\
\end{array}$ & $\begin{array}{c}(4) \\
\text { FE (No MV) }\end{array}$ & $\begin{array}{c}(5) \\
\text { FE (Less Empl) } \\
\end{array}$ \\
\hline \multicolumn{6}{|l|}{ EPL - (1996) } \\
\hline TGxReform(t-1) & & $\begin{array}{l}0.0487 \\
(0.081)\end{array}$ & $\begin{array}{l}0.0696 \\
(0.080)\end{array}$ & $\begin{array}{c}0.103 \\
(0.087)\end{array}$ & $\begin{array}{c}0.142 \\
(0.097)\end{array}$ \\
\hline TGxReform & $\begin{array}{r}-0.0426 \\
(0.068)\end{array}$ & $\begin{array}{l}-0.0943 \\
(0.085)\end{array}$ & $\begin{array}{l}-0.0809 \\
(0.085)\end{array}$ & $\begin{array}{r}-0.0909 \\
(0.087)\end{array}$ & $\begin{array}{l}-0.0995 \\
(0.095)\end{array}$ \\
\hline TGxReform $(t+1)$ & & $\begin{array}{l}0.0643 \\
(0.079)\end{array}$ & $\begin{array}{l}0.0555 \\
(0.079)\end{array}$ & $\begin{array}{l}0.0645 \\
(0.079)\end{array}$ & $\begin{array}{l}0.0512 \\
(0.086)\end{array}$ \\
\hline Socio-demo. controls & no & no & yes & yes & yes \\
\hline$N$ & 5,917 & 5,917 & 5,917 & 5,485 & 4,633 \\
\hline$R^{2}$ & 0.007 & 0.008 & 0.026 & 0.031 & 0.034 \\
\hline \multicolumn{6}{|l|}{$\mathrm{EPL}+(1999)$} \\
\hline TGxReform(t-1) & & $\begin{array}{l}0.0229 \\
(0.082)\end{array}$ & $\begin{array}{l}0.0261 \\
(0.081)\end{array}$ & $\begin{array}{l}0.0189 \\
(0.086)\end{array}$ & $\begin{array}{r}-0.0857 \\
(0.094)\end{array}$ \\
\hline TGxReform & $\begin{array}{r}-0.0121 \\
(0.061)\end{array}$ & $\begin{array}{r}-0.0325 \\
(0.075)\end{array}$ & $\begin{array}{r}-0.0191 \\
(0.075)\end{array}$ & $\begin{array}{r}-0.0357 \\
(0.075)\end{array}$ & $\begin{array}{c}-0.000727 \\
(0.083)\end{array}$ \\
\hline TGxReform $(t+1)$ & & $\begin{array}{l}0.0215 \\
(0.079)\end{array}$ & $\begin{array}{l}0.0439 \\
(0.079)\end{array}$ & $\begin{array}{l}0.0468 \\
(0.078)\end{array}$ & $\begin{array}{l}0.0338 \\
(0.087)\end{array}$ \\
\hline Socio-demo. controls & no & no & yes & yes & yes \\
\hline$N$ & 9,255 & 9,255 & 9,255 & 7,220 & 5,916 \\
\hline$R^{2}$ & 0.001 & 0.001 & 0.011 & 0.016 & 0.016 \\
\hline $\begin{array}{l}\text { Note: Fixed effects mod } \\
p<0.05,{ }^{* *} p<0.01 ; \mathrm{T} \\
\text { year]; Reform }(\mathrm{t}-1)=[1 \mathrm{i} \\
>=\text { one year after the } \mathrm{r} \\
\text { remain in a temporary } / \mathrm{p} \\
\text { in TG or CG over the sa } \\
\text { valid answer to the perc } \\
\text { workers who perceive it } \\
\text { reform dummies, TG, y } \\
\text { monthly HH income, wo } \\
\text { child dummies as well st }\end{array}$ & $\begin{array}{l}\text { f year }>= \\
\text { eform year } \\
\text { ermanent } \\
\text { mple perio } \\
\text { eption of } f \\
\text { to be prac } \\
\text { ear fixed }\end{array}$ & $\begin{array}{l}\text { lustered } \mathrm{s} \\
-19 \text { and TC } \\
\text { one year be } \\
\text { c]; Sample } \\
\text { job over th } \\
\text { d); No mi } \\
\text { inding a n } \\
\text { tically imp }\end{array}$ & $\begin{array}{l}\text { andard er } \\
=0 \text { if } 20 \\
\text { ore the re } \\
\text { 3: remain } \\
\text { sample } 1 \\
\text { sing value } \\
\text { w job; les } \\
\text { ssible or } \\
\text { o-demogr }\end{array}$ & $\begin{array}{l}\text { ors in parenthes } \\
\text { 199; Reform }=[1 \\
\text { orm year]; Refor } \\
\text { in the contract } \\
\text { riod), stayers (n } \\
\text { (No MV): sampl } \\
\text { employable (les } \\
\text { ifficult to find a } \\
\text { phic (socio-dem }\end{array}$ & $\begin{array}{l}\text { s; }{ }^{*} p<0.10,{ }^{* *} \\
\text { if year }>=\text { reform } \\
(\mathrm{t}+1)=[1 \text { if year } \\
\text { rm (workers who } \\
\text { orkers who remain } \\
\text { of workers with a } \\
\text { empl): sample of } \\
\text { new job; Controls: } \\
\text { ) controls: log of } \\
\text { female, married, }\end{array}$ \\
\hline
\end{tabular}

Table 6: Share of less employable temporary workers moving into CG or TG firms

\begin{tabular}{cccc}
\hline \hline & Into TG from CG & Stayer & Into CG from TG \\
\hline 1995 & 2.20 & 83.52 & 14.29 \\
1996 & 7.79 & 83.12 & 9.09 \\
1997 & 4.00 & 93.00 & 3.00 \\
\hline \hline
\end{tabular}

Note: Treatment group (TG), control group (CG); TG = 1 if 5-19 and $\mathrm{TG}=0$ if 20-199; "Into TG from CG" means that the worker moves in the next observed period from TG into CG; Sample B: remain temporary(temp)/permanent(perm) (workers who remain in a temporary/permanent job over the sample period), stayers (workers who remain in TG or CG over the sample period). 
For instance, the decrease in life satisfaction by 0.703 units of less-employable temporary workers due to a decrease in EPLP in 1996 (Table 4) is robust to changes to the ending month (January 0.702 and December 0.703). ${ }^{37}$ With regard to the 1999 reform, the policy effect is robust to different sample periods, too.

\section{Conclusion and discussion}

This study investigates the impact of two almost perfectly symmetric reforms (1996, 1999) in German employment protection legislation for permanent contracts on wellbeing. EPLP reforms vary by firm size and allow for a difference-in-difference approach. Thus, I combine standard evaluation tools in the literature on the effects of employment protection on objective outcomes with the literature on determinants of life satisfaction for the first time. To identify the effects, I use longitudinal data of the GSOEP allowing me to control for individual fixed effects. In order to address potential violation of the common trend assumption required for the DID approach, e.g. due to worker selection, I account for a broad set of observables as well as for time-invariant unobservables. Also, I conduct placebo-tests, and pre-treatment trend tests. A major drawback is that the GSOEP allows me to measure firm size only imprecisely, which is likely to bias the policy effect estimator towards zero.

Following the literature, I distinguish between effects on temporary and permanent workers at points of the reform. The main result is that temporary workers suffered in terms of life satisfaction, on average, from a decrease in EPLP in 1996. A plausible explanation for this finding would be social comparison. Centeno and Novo (2012) found that EPLP is negatively related with transition probabilities from temporary to permanent work. Hence, temporary workers who remain temporarily employed might suffer due to comparison with colleagues who transitioned successfully in a permanent job after the reform. Common pre-reform trends show that treatment and control group do not differ in their pre-reform trend controlling for observable and time-invariant unobservable heterogeneity. This might at least reduce concerns about the relevance of unobserved time-variant heterogeneity for the policy effect. The increase in EPLP had no significant effect on well-being which would be, however, in line with the literature on loss aversion. As the EPLP reforms affected newly hired workers but less incumbents, a large proportion of permanent workers were not affected from the decrease and increase in EPLP. Hence, I did not expect strong effects of the reforms on their well-being, which is confirmed.

\footnotetext{
${ }^{37}$ See Appendix C, columns (4) to (6) in Table 12.
} 
In the aftermath of the 2007 financial crisis, decreasing EPLP was often discussed and liberalizing reforms took place, e.g. in Spain. Policy makers should account for potential negative well-being effects of a decrease in EPLP on temporary workers when designing such reforms. Based on that, a deeper investigation of the mechanisms which I discuss in the paper (e.g. comparison and anticipation hypotheses) would be interesting to investigate. As I cannot mitigate all the remaining concerns about the relevance of time-invariant unobservables for the policy effect, future research which explores other sources of variation in EPLP would be beneficial in order to investigate the relevance of the remaining concerns. In general, combining standard evaluation techniques to study the effect of labor market institutions and policies with research on determinants of well-being proxied by life satisfaction seems to be a fruitful task for future research. Research in this area is still rare with important exceptions: Hamermesh, Kawaguchi, and Lee (2014), Dorsett and Oswald (2014), D'Addio, Chapple, Hoherz, and Landeghem (2014), Montizaan and Vendrik (2014), Kuroki (2012), and Lepage-Saucier and Wasmer (2012). This is surprising given that well-being is frequently applied in economic research (e.g. Hetschko, Knabe, and Schöb, 2014; Frey and Stutzer, 2012; Clark and Senik, 2010) as well as in public policy (e.g. OECD, 2013, 2011; Oswald, 2010). 


\section{References}

Autor, D. H. (2003): "Outsourcing at will: The contribution of unjust dismissal doctrine to the growth of employment outsourcing," Journal of Labor Economics, 21(1), 1-42.

Bauer, T. K., S. Bender, And H. Bonin (2007): "Dismissal Protection and Worker Flows in Small Establishments," Economica, 74, 804-821.

Benjamin, D. J., O. Heffetz, M. S. Kimball, and A. Rees-Jones (2012): "What do you think would make you happier? What do you think you would choose?," American Economic Review, 102(5), 2083-2110.

Boarini, R., M. Comola, F. D. Keulenaer, R. Manchin, and C. Smith (2013): "Can Governments Boost People's Sense of Well-Being? The Impact of Selected Labour Market and Health Policies on Life Satisfaction," Social Indicators Research, 114(1), 105-120.

Boeri, T. (2011): "Institutional reforms and dualism in European labor markets," in Handbook of Labor Economics, ed. by O. Ashenfelter, and D. Card, vol. 4B, pp. 1173-1236. Elsevier, Amsterdam.

Boeri, T., And P. Garibaldi (2007): "Two-Tier Reforms of Employment Protection: A Honeymoon Effect?," The Economic Journal, 117(521), F357-F385.

Boeri, T., And J. F. Jimeno (2005): "The Effects of Employment Protection: Learning from Variable Enforcement," European Economic Review, 49(8), 20572077.

Boockmann, B., D. Gutknecht, and S. Steffes (2008): "The effect of dismissal protection legislation on the stability of newly started employment relation," Journal for Labour Market Research, 41(2/3), 347-364.

Boockmann, B., And T. Hagen (2001): "The Use of Flexible Working Contracts in West Germany: Evidence from an Establishment Panel," ZEW Discussion Paper, 01-33, 1-32.

Booth, A. L., M. Francesconi, and F. Frank (2002): "Temporary Jobs: Stepping Stones or Dead Ends?," Economic Journal, 112(480), F189-F213.

Boyce, C. J., A. M. Wood, J. Banks, A. E. Clark, and G. D. A. Brown (2013): "Money, Well-Being and Loss Aversion: Does an Income Loss Have a Greater Effect on Well-Being Than an Equivalent Income Gain?," Psychological Science, 24(12), 2557-2562.

Busk, H., E. J. Jahn, and C. Singer (2015): "Do changes in regulation affect temporary agency workers' job satisfaction?," IZA Discussion Paper, 8803.

Cahuc, P., O. Charlot, and F. Malherbert (2012): "Explaining the Spread of Temporary Jobs and its Impact on Labor Turnover," IZA Discussion Paper, 6365 .

Cahuc, P., And W. Koeniger (2007): "Feature: Employment protection legislation," The Economic Journal, 117(521), F185-F188.

Campbell, D., A. Carruth, A. Dickerson, and F. Green (2007): "Job insecurity and wages," Economic Journal, 117(518), 544-566. 
Cappellari, L., C. Dell'Aringa, and M. Leonardi (2012): "Temporary employment, job flows and productivity: A tale of two reforms," The Economic Journal, 122(562), F188-F215.

Centeno, M., and A. A. Novo (2012): "Excecss Worker Turnover and FixedTerm Contracts: Causal Evidence in a Two-Tier System," Labour Economics, 19, $320-328$.

Chadi, A., And C. Hetschko (2014): "The Magic of the New: How Job Changes Affect Job Satisfaction," IAAEU Discussion Paper, 5.

Cheng, G. H. L., and D. K. S. Chan (2008): "Who suffers more from job insecurity? A meta-analytic review," Applied Psychology: An International Review, $57(2), 272-303$.

Clark, A. E., E. Diener, Y. Georgellis, and R. E. Lucas (2008): "Lags and Leads in Life Satisfaction: A Test of the Baseline Hypothesis," The Economic Journal, 118, F222-F243.

Clark, A. E., And F. Postel-Vinay (2009): "Job-Security and Job-Protection," Oxford Economic Papers, 61(2), 207-239.

Clark, A. E., and C. Senik (2010): "Who Compares to Whom? The Anatomy of Income Comparisons in Europe," The Economic Journal, 120(544), 573-594.

D'Addio, A. D., S. Chapple, A. Hoherz, and B. V. Landeghem (2014): "Using a quasi-natural experiment to identify the effects of birth-related leave policies on subjective well-being in Europe," OECD Journal: Economic Studies, 7, 235-268.

De Witte, H. (2005): "Job insecurity: Review of the international literature on definitions, prevalence, antecedents and consequences," SA Journal of Industrial Psychology, 31(4), 1-6.

Dorsett, R., And A. J. Oswald (2014): "Human Well-Being and In-WorkBenefits: A Randomized Controlled Trial," IZA Discussion Paper, 7943.

EASterlin, R. A. (1974): "Does economic growth improve the human lot? Some empirical evidence," in Nations and Households in Economic Growth: Essays in Honor of Moses Abramowitz, ed. by P. A. David, and M. W. Reder, pp. 89-125. Academic Press, New York.

Easterlin, R. A., L. A. McVey, M. Switek, O. Sawangfa, and J. S. Zweig (2010): "The happiness-income Paradox revisited," Proceedings of the National Academy of Sciences (PNAS), 107(52), 22463-22468.

FalK, A., And M. Knell (2004): "Choosing the Joneses: Endogenous Goals and Reference Standards," Scandinavian Journal of Economics, 106(3), 417-435.

Ferrer-I-Carbonell, A., And P. Frijters (2004): "How important is methodology for the estimates of the determinants of happiness?," The Economic Journal, 114(497), 641-659.

Frey, B., And A. Stutzer (2012): "The Use of Happiness Research for Public Policy," Social Choice Welfare, 38(4), 689-674. 
Geishecker, I. (2012): "Simultaneity bias in the analysis of perceived job insecurity and subjective wel-being," Economics Letters, 116(3), 319-321.

Green, F. (2011): "Unpacking the misery multiplier: How employability modifies the impacts of unemployment and job insecurity on life satisfaction and mental health," Journal of Health Economics, 30(2), 265-276.

Haisken-DeNew, J. P., And J. Frick (2005): "Desktop Companion to the German socioeconomic panel study (GSOEP)," Technical Report, German Institute for Economic Research: Berlin.

Hamermesh, D. S., D. Kawaguchi, and J. Lee (2014): "Does labor legislation benefit workers? Well-being after an hours reduction," NBER Working Paper, 20398.

Hetschko, C., A. Knabe, and R. Sснӧв (2014): "Changing identity: Retiring from unemployment," The Economic Journal, 124(575), 149-166.

Iverson, R. D., And C. Maguire (2000): "The relationship between job and life satisfaction: Evidence from a remote mining community," Human Relations, 53(6), 807-839.

JudGe, A. T., AND E. A. Locke (1993): "Effect of dysfunctional thought processes on subjective well-being and job satisfaction," Journal of Applied Psychology, 78, $475-490$.

KaHn, L. M. (2007): "The Impact of Employment Protection Mandates on Demographic Temporary Employment Patterns: International Microeconomic Evidence," The Economic Journal, 117(521), 333-356.

Kahneman, D., and A. B. Krueger (2006): "Developments in the measurement of subjective well-being," Journal of Economic Perspectives, 20(1), 3-24.

Karacuka, M., And A. Zaman (2012): "The empirical evidence against neoclassical utility theory: a review of the literature," International Journal of Pluralism and Economics Education, 3(2), 366-414.

Kassenboehmer, S. C., and J. P. Haisken-DeNew (2009): "You're Fired! The Causal Negative Effect of Entry Unemployment on Life Satisfaction," The Economic Journal, 119(536), 448-462.

Krause, A. (2013): "Don't Worry, Be Happy? Happiness and Reemployment," Journal of Economic Behavior and Organization, 96, 1-20.

Kugler, A., And G. PiCA (2008): "Effects of Employment Protection on Worker and Job Flows: Evidence from the 1990 Italian Reform," Labour Economics, (1).

Kuroki, M. (2012): "The Deregulation of Temporary Employment and Workers' Perceptions of Job Insecurity," Industrial and Labor Relations Review, 65(3), 560577.

LAZAeR, E. P. (1990): "Job Security Provisions and Employment," Quarterly Journal of Economics, 105(3), 699-726.

LeOnardi, M., And G. PiCA (2013): "Who pays for it? The heterogeneous wage effects of employment protection legislation," The Economic Journal, 123(573), $1236-1278$. 
Lepage-Saucier, N., And E. Wasmer (2012): "Does employment protection raise stress? A cross-country and cross-province analysis," Conference paper Economic Policy (fifty-fifth Panel Meeting).

LindBeck, A., AND D. J. SNOwer (2001): "Insiders versus Outsiders," Journal of Economic Perspectives, 15(1), 165-188.

Luttmer, E. F. P. (2005): "Neighbors as negatives: Relative earnings and wellbeing," The Quarterly Journal of Economics, 120(3), 963-1002.

Marinescu, I. (2009): "Job Security Legislation and Job Duration: Evidence from the United Kingdom," Journal of Labor Economics, 27(3), 465-486.

Martins, P. S. (2009): "Dismissals for Cause: The Difference that just Eight Paragraphs Can Make," Journal of Labor Economics, 272(2), 257-279.

MontizaAn, R. M., And M. Vendrik (2014): "Misery loves company: Exogenous shocks in retirement expectations and social comparison effects on subjective wellbeing," Journal of Economic Behavior and Organization, 97, 1-26.

Nunziata, L., and S. Staffolani (2007): "Short-Term Contracts Regulations and Dynamic Labour Demand: Theory and Evidence," Scottish Journal of Political Economy, 54(1), 72-104.

Ochsen, C., And H. Welsch (2012): "Who benefits from labor market institutions? Evidence from surveys of life satisfaction," Journal of Economic Psychology, $33(1), 112-124$.

OECD (2011): How's life? Mesuring Well-Being. OECD Publishing, Paris.

(2013): OECD Employment Outlook 2013. OECD Publishing, Paris.

- (2015): Statistics Database, accessed at http://stats.oecd.org/ (April 2015).

Oswald, A. J. (2010): "Emotional prosperity and the Stiglitz Commission," British Journal of Industrial Relations, 48(4), 651-669.

Oswald, A. J., E. Proto, And D. SGroi (2013): "Happiness and Productivity," CAGE University of Warwick Online Working Paper Series, 2013, 1-24.

Praag, B. M. S. V., P. Frijters, and A. Ferrer-I-Carbonell (2003): "The anatomy of subjective well-being," Journal of Economic Behavior and Organization, 51, 29-49.

RuEDA, D. (2005): "Insider-outsider politics in industrialized democracies: The challenge to social democratic parties," American Political Science Review, 99(1), $61-74$.

SALVATORI, A. (2010): "Labour contract regulations and worker's wellbeing: International longitudinal evidence," Labour Economics, 17, 667-678.

Scoppa, V. (2010): "Shirking and employment protection legislation: Evidence from a natural experiment," Economic Letters 10\%, 107, 276-280.

Stevenson, B., And J. Wolfers (2008): "Economic growth and subjective wellbeing: reassessing the Easterlin Paradox," Brookings Papers on Economic Activity, pp. 1-102. 
Sverke, M., J. Hellgren, and K. NÄswall (2002): "No security: A metaanalysis and review of job insecurity and its consequences," Journal of Occupational Health Psychology, 7(3), 242-264.

Venn, D. (2009): "Legislation, Collective Bargaining and Enforcement: Updating the OECD Employment Protection Indicators," OECD Social, Employment and Migration Working Papers, 89.

WARr, P. (2003): "Well-being and the workplace," in Well-Being: The Foundations of Hedonic Psychology, ed. by D. Kahneman, E. Dieners, and N. Schwarz. Russell Sage Foundation, New York. 


\section{A Descriptive statistics}

Table 7: Descriptive statistics: temporary workers who remain temporary employees

\begin{tabular}{lccccc}
\hline \hline \multicolumn{1}{c}{ Variable } & Mean & Std. Dev. & Min. & Max. & No. \\
\hline EPL - (1996) & & & & & \\
Pre-reform period & & & & & \\
\hline life satisfaction & 7.078 & 1.706 & 1 & 10 & 319 \\
job satisfaction & 7.097 & 2.07 & 0 & 10 & 319 \\
job security & 1.997 & 0.799 & 1 & 3 & 319 \\
monthly HH net income $(€)$ & $2,049.887$ & 803.545 & 511 & 4,704 & 319 \\
age & 26.665 & 11.12 & 17 & 58 & 319 \\
female & 0.498 & 0.501 & 0 & 1 & 319 \\
Post-reform period & & & & & \\
\hline life satisfaction & 6.977 & 1.796 & 0 & 10 & 305 \\
job satisfaction & 7.075 & 2.168 & 0 & 10 & 305 \\
job security & 1.98 & 0.761 & 1 & 3 & 305 \\
monthly HH net income $(€)$ & $2,159.207$ & 904.051 & 460 & 5,266 & 305 \\
age & 25.603 & 10.349 & 17 & 59 & 305 \\
female & 0.439 & 0.497 & 0 & 1 & 305 \\
\hline EPL + (1999) & & & & & \\
Pre-reform period & & & & & \\
\hline life satisfaction & 7.064 & 1.753 & 0 & 10 & 358 \\
job satisfaction & 7.148 & 2.052 & 0 & 10 & 358 \\
job security & 1.98 & 0.765 & 1 & 3 & 358 \\
monthly HH net income $(€)$ & $2,178.564$ & 905.288 & 557 & 5,624 & 358 \\
age & 25.249 & 9.968 & 17 & 58 & 358 \\
female & 0.439 & 0.497 & 0 & 1 & 358 \\
Post-reform period & & & & & \\
\hline life satisfaction & 7.105 & 1.694 & 1 & 10 & 797 \\
job satisfaction & 7.118 & 2.083 & 0 & 10 & 797 \\
job security & 2.049 & 0.741 & 1 & 3 & 797 \\
monthly HH net income $(€)$ & $2,282.748$ & 903.451 & 511 & 5,624 & 797 \\
age & 26.955 & 10.921 & 17 & 61 & 797 \\
female & 0.484 & 0.5 & 0 & 1 & 797 \\
\hline
\end{tabular}

Note: Reform 1996: pre-reform period 01.01.1995-31.09.1996, post-reform period 01.10.1996-31.12.1998; Reform 1999: pre-reform period 01.01.1997-31.12.1998, postreform period 01.01.1999-31.12.2001; Sample B: stayers (workers who remain in TG or CG), workers in a temporary job and in firms with 5-199 employees at the date of observation. Source: Own calculation based on GSOEP. 
Table 8: Descriptive statistics: permanent workers who remain permanent employees

\begin{tabular}{|c|c|c|c|c|c|}
\hline Variable & Mean & Std. Dev. & Min. & Max. & No. \\
\hline \multicolumn{6}{|l|}{ EPL - (1996) } \\
\hline \multicolumn{6}{|l|}{ Pre-reform period } \\
\hline life satisfaction & 7.069 & 1.569 & 0 & 10 & 3,091 \\
\hline job satisfaction & 7.039 & 1.98 & 0 & 10 & 3,091 \\
\hline job security & 2.354 & 0.685 & 1 & 3 & 3,091 \\
\hline monthly HH net income $(€)$ & $2,200.121$ & 809.201 & 767 & 5,670 & 3,091 \\
\hline age & 39.839 & 10.526 & 17 & 65 & 3,091 \\
\hline female & 0.424 & 0.494 & 0 & 1 & 3,091 \\
\hline \multicolumn{6}{|l|}{ Post-reform period } \\
\hline life satisfaction & 6.989 & 1.565 & 0 & 10 & 2,826 \\
\hline job satisfaction & 6.961 & 1.925 & 0 & 10 & 2,826 \\
\hline job security & 2.202 & 0.699 & 1 & 3 & 2,826 \\
\hline monthly HH net income $(€)$ & $2,261.674$ & 814.505 & 767 & 5,624 & 2,826 \\
\hline age & 40.782 & 10.233 & 21 & 65 & 2,826 \\
\hline female & 0.424 & 0.494 & 0 & 1 & 2,826 \\
\hline \multicolumn{6}{|l|}{$\mathrm{EPL}+(1999)$} \\
\hline \multicolumn{6}{|l|}{ Pre-reform period } \\
\hline life satisfaction & 7.027 & 1.564 & 0 & 10 & 3,084 \\
\hline job satisfaction & 7.021 & 1.896 & 0 & 10 & 3,084 \\
\hline job security & 2.207 & 0.700 & 1 & 3 & 3,084 \\
\hline monthly HH net income $(€)$ & $2,284.295$ & 833.399 & 818 & 5,697 & 3,084 \\
\hline age & 40.425 & 10.099 & 19 & 65 & 3,084 \\
\hline female & 0.431 & 0.495 & 0 & 1 & 3,084 \\
\hline \multicolumn{6}{|l|}{ Post-reform period } \\
\hline life satisfaction & 7.188 & 1.536 & 0 & 10 & 6,171 \\
\hline job satisfaction & 7.077 & 1.903 & 0 & 10 & 6,171 \\
\hline job security & 2.285 & 0.689 & 1 & 3 & 6,171 \\
\hline monthly HH net income $(€)$ & $2,408.497$ & 851.719 & 818 & 5,880 & 6,171 \\
\hline age & 41.791 & 9.854 & 19 & 65 & 6,171 \\
\hline female & 0.439 & 0.496 & 0 & 1 & 6,171 \\
\hline
\end{tabular}

Note: Restricted to permanent workers in firms with 5-199 employees (at least 12 months in their job); Reform 1996: pre-reform period 01.01.1995-31.09.1996, postreform period 01.10.1996-31.12.1998; Reform 1999: pre-reform period 01.01.199731.12.1998, post-reform period 01.01.1999-31.12.2001; Sample B: stayers (workers who remain in TG or CG), workers in a permanent job and in firms with 5-199 employees at the date of observation. Source: Own calculation based on GSOEP. 


\section{B Common trend assumption}

This section provides additional analyses of the common trend assumption for Sample B. I proceed as follows: First, I provide placebo tests, which are typically conducted in the literature on EPLP evaluation (e.g. Leonardi and Pica, 2013); Second, I proceed by a detailed analyses of a potential pre-treatment trend difference between control and treatment group.

\section{Placebo tests}

In this part, I provide placebo tests for Sample B and for the subsample of Sample B of less-employable workers. Overall, placebo tests support the common trend assumption for life satisfaction as the outcome variable. In order to conduct a placebo group tests, I define workers to be in the treatment group, when they work in firms with 20-199 workers, and to be in the control group, when they are employed in firms larger than 199 workers. Hence, both groups of workers did not face any changes. If the policy effect is different from zero, then the general dynamic between small and large firms differ. The policy effects are, however, not significant - neither for the 1996 nor for the 1999 reform (Table 9). In order to conduct a placebo reform test, I define a placebo reform dummy for 1998 and choose a sample period from 1996 to 1999. I do not find that there is a general different dynamic in life satisfaction for workers in 5-19 versus 20-199 sized firms (Table 10).

Table 9: Dependent variable: life satisfaction (pseudo group)

\begin{tabular}{|c|c|c|c|c|}
\hline & $\begin{array}{l}\text { (1) } \\
\text { FE }\end{array}$ & $\begin{array}{c}(2) \\
\text { FE (Less Empl) }\end{array}$ & $\begin{array}{l}(3) \\
\text { FE }\end{array}$ & $\begin{array}{c}(4) \\
\text { FE (Less Empl) }\end{array}$ \\
\hline & \multicolumn{2}{|c|}{ Temporary workers (remain) } & \multicolumn{2}{|c|}{ Permanent workers (remain) } \\
\hline \multicolumn{5}{|l|}{ EPL - (1996) } \\
\hline TGxReform & $\begin{array}{c}-0.0626 \\
(0.302)\end{array}$ & $\begin{array}{l}-0.187 \\
(0.339)\end{array}$ & $\begin{array}{l}0.0518 \\
(0.059)\end{array}$ & $\begin{array}{l}0.0798 \\
(0.065)\end{array}$ \\
\hline$N$ & 824 & 584 & 10,836 & 8,819 \\
\hline \multicolumn{5}{|l|}{$\mathrm{EPL}+(1999)$} \\
\hline TGxReform & $\begin{array}{c}0.263 \\
(0.239)\end{array}$ & $\begin{array}{c}0.404 \\
(0.261)\end{array}$ & $\begin{array}{l}0.0361 \\
(0.056)\end{array}$ & $\begin{array}{l}0.0521 \\
(0.062)\end{array}$ \\
\hline$N$ & 1,464 & 786 & 16,459 & 10,778 \\
\hline
\end{tabular}

Note: Fixed effects model (FE), clustered standard errors in parentheses; ${ }^{*} p<0.10,{ }^{* *} p<$ $0.05,{ }^{* * *} p<0.01 ; \mathrm{TG}=1$ if $20-199$ and TG $=0$ if 200-1999; Reform $=[1$ if year $>=$ reform year $]$; Reform $(\mathrm{t}-1)=[1$ if year $>=$ one year before the reform year $]$; Reform $(\mathrm{t}+1)=[1$ if year $>=$ one year after the reform year]; Sample B: Permanent/temporary workers (remain) are workers who remain in a temporary/permanent job over the sample period and who remain in TG or CG over the sample period); less employable (less empl): sample of workers who perceive it to be practically impossible or difficult to find a new job; Controls: reform dummies, TG, year fixed effects, TGxReform(t+1), TGxReform(t-1); Socio-demographic (socio-demo.) controls: log of monthly HH income, working hours, working hours ${ }^{2}$, age, age $^{2}$, education, female, married, child dummies as well state fixed effects.

\section{Pre-treatment trend}

In this part, I investigate in detail the pre-treatment trend of control and treatment group for Sample B and for the subsample of Sample B of less-employable workers. I 
Table 10: Dependent variable: life satisfaction (placebo reform 1998)

\begin{tabular}{|c|c|c|}
\hline & (1) & $(2)$ \\
\hline & FE & FE \\
\hline & Temporary workers (remain) & Permanent workers (remain) \\
\hline \multirow[t]{2}{*}{ TGxReform } & 0.437 & 0.0474 \\
\hline & $(0.284)$ & $(0.077)$ \\
\hline$N$ & 662 & 6,030 \\
\hline$R^{2}$ & 0.064 & 0.022 \\
\hline \multicolumn{3}{|c|}{$\begin{array}{l}\text { Note: Fixed effects model (FE), clustered standard errors in parentheses; }{ }^{*} p<0.10,{ }^{* *} \\
p<0.05,{ }^{* * *} p<0.01 ; \mathrm{TG}=1 \text { if } 5-19 \text { and TG }=0 \text { if } 20-199 ; \text { Reform }=[1 \text { if year }>=1998 \\
\text { year]; Reform(t-1)=[1 if year }>=1997] \text {; Reform }(\mathrm{t}+1)=[1 \text { if year }>=1999] \text {; Sample B: } \\
\text { Permanent/temporary workers (remain) are workers who remain in a temporary/permanent } \\
\text { job over the sample period and who remain in TG or CG over the sample period); Con- } \\
\text { trols: reform dummies, TG, year fixed effects, TGxReform }(\mathrm{t}+1) \text {, TGxReform(t-1); Socio- } \\
\text { demographic (socio-demo.) controls: log of monthly HH income, working hours, working } \\
\text { hours }{ }^{2} \text {, age, age }{ }^{2} \text {, education, female, married, child dummies as well state fixed effects. }\end{array}$} \\
\hline
\end{tabular}

investigate life satisfaction, job security and job satisfaction as dependent variables. This analyses was conducted as a pre-analyses in order to decide whether the common trend assumption is at least met in the pre-treatment period. If this was not the case, I do not derive implications from the respective model.

I proceed as follows: First, I test whether control and treatment group differ in their pre-treatment trend; Second, if I find a different pre-treatment trends between control and treatment group in a specific regression, I test whether anticipation explains this; Third, if this is not the case, I do not consider this specific model in this paper.

First, concerning life satisfaction, the models in Tables 3, 4, and 5 test, whether there is a trend difference between control and treatment group in the period before the reform takes place. For life satisfaction equations, there are no pre-treatment trend differences. Concerning the job security and the job satisfaction equation, I find the pre-policy effect for the decrease in EPLP in 1996 of temporary workers to be significant, which is specifically the case for less-employable workers. ${ }^{38}$

Second, in Table 11, I test whether the aforementioned pre-reform differences for the 1996 reform in job security of less employable temporary workers or job satisfaction of less employable temporary workers are due to an anticipation of the reform. If the pre-policy effect is due to anticipation, exclusion of the time period, in which the reforms were already discussed, can abolish the pre-policy effect. The discussion for the 1996 reform intensified in May 1996. ${ }^{39}$ Hence, I restrict the sample for the 1996 reform to a period from January 1995 to April 1996, and from October 1996 to December 1998. Table 11 presents results for the two models. The restricted samples are in the lower part. The pre-policy effects decrease, but I interpret this as not substantial. In order to mitigate any concerns, I do not consider job satisfaction and perceived job security in this paper.

Third, I conclude from the analyses, that the life satisfaction equations are not problematic in terms of pre-treatment trend differences between control and treatment group. I cannot, however, confirm this for job security and job satisfaction equations. Therefore, I focus in the paper on life satisfaction as the outcome and do not extend the paper to job security and job satisfaction. This would be interesting, however, in order to investigate potential channels for the effect of EPLP on life

\footnotetext{
${ }^{38}$ Results are available upon request.

${ }^{39}$ Based on research in the online archive of the newspaper DIE ZEIT.
} 
satisfaction.

Table 11: Is anticipation relevant?

\begin{tabular}{|c|c|c|}
\hline & $\begin{array}{c}(1) \\
\text { LPM FE(less empl) }\end{array}$ & $\begin{array}{c}(2) \\
\text { FE(less empl) }\end{array}$ \\
\hline & \multicolumn{2}{|c|}{ Temporary workers (remain) } \\
\hline Dependent Var. & JoSec & JobSat \\
\hline Sample Period & $1995-1998$ & $1995-1998$ \\
\hline TGxReform(t-1) & $\begin{array}{l}0.283^{* *} \\
(0.122)\end{array}$ & $\begin{array}{l}0.963^{*} \\
(0.540)\end{array}$ \\
\hline TGxReform & $\begin{array}{c}-0.238^{* *} \\
(0.115)\end{array}$ & $\begin{array}{l}-0.220 \\
(0.463)\end{array}$ \\
\hline TGxReform $(\mathrm{t}+1)$ & $\begin{array}{l}0.0556 \\
(0.097)\end{array}$ & $\begin{array}{l}0.869^{* *} \\
(0.430)\end{array}$ \\
\hline$N$ & 404 & 404 \\
\hline$R^{2}$ & 0.100 & 0.151 \\
\hline Sample Period & 95-96, 10.96-98 & $95-4.96,10.96-98$ \\
\hline TGxReform(t-1) & $\begin{array}{l}0.219^{*} \\
(0.124)\end{array}$ & $\begin{array}{c}0.905 \\
(0.551)\end{array}$ \\
\hline TGxReform & $\begin{array}{l}-0.122 \\
(0.120)\end{array}$ & $\begin{array}{l}-0.160 \\
(0.500)\end{array}$ \\
\hline TGxReform $(t+1)$ & $\begin{array}{l}0.0723 \\
(0.098)\end{array}$ & $\begin{array}{l}0.872^{* *} \\
(0.427)\end{array}$ \\
\hline$N$ & 382 & 382 \\
\hline$R^{2}$ & 0.089 & 0.164 \\
\hline
\end{tabular}

Note: Linear probability model (LPM), fixed effects model (FE), clustered standard errors in parentheses; ${ }^{*} p<0.10,{ }^{* *} p<0.05,{ }^{* * *} p<0.01$; TG $=1$ if $5-19$ and $\mathrm{TG}=0$ if $20-199$; Reform $=[1$ if year $>=$ reform year]; Reform(t- 1 ) $=[1$ if year $>=$ one year before the reform year $]$; Reform $(t+1)=[1$ if year $>=$ one year after the reform year]; JobSat: job satisfaction; JobSec: perceived job security $(0,1)$; Sample B: temporary workers (remain) are workers who remain in a temporary job over the sample period and who remain in TG or CG over the sample period; less employable (less empl): sample of workers who perceive it to be practically impossible or difficult to find a new job; Controls: reform dummies, TG, year fixed effects; Socio-demographic (socio-demo.) controls: log of monthly $\mathrm{HH}$ income, working hours, working hours ${ }^{2}$, age, age ${ }^{2}$, education, female, married, child dummies as well state fixed effects. 


\section{Robustness: sample period, movers and stayers}

Table 12: Dependent variable: life satisfaction of less empl. workers (EPL- (1996))

\begin{tabular}{lcccccc}
\hline \hline & $(1)$ & $\begin{array}{c}\text { Movers } \\
(2)\end{array}$ & $(3)$ & $(4)$ & $\begin{array}{c}\text { Stayers } \\
(5)\end{array}$ & $(6)$ \\
& FE(Jan) & FE(May) & FE(Dec) & FE(Jan) & FE(May) & FE(Dec) \\
\hline TGxReform(t-1) & -0.281 & -0.350 & -0.359 & -0.113 & -0.190 & -0.211 \\
& $(0.392)$ & $(0.388)$ & $(0.388)$ & $(0.422)$ & $(0.417)$ & $(0.417)$ \\
TGxReform & -0.612 & -0.579 & -0.584 & -0.702 & $-0.699^{*}$ & $-0.703^{*}$ \\
& $(0.444)$ & $(0.405)$ & $(0.403)$ & $(0.452)$ & $(0.416)$ & $(0.417)$ \\
TGxReform(t+1) & 0.675 & 0.545 & $0.575^{*}$ & $1.290^{*}$ & $0.654^{*}$ & $0.674^{* *}$ \\
& $(0.628)$ & $(0.340)$ & $(0.324)$ & $(0.671)$ & $(0.359)$ & $(0.341)$ \\
\hline$N$ & 394 & 475 & 483 & 325 & 398 & 404 \\
$R^{2}$ & 0.140 & 0.126 & 0.125 & 0.192 & 0.175 & 0.172 \\
\hline & \multicolumn{5}{c}{ Permanent workers $($ remain } & permanent) \\
\hline TGxReform(t-1) & 0.0940 & 0.107 & 0.103 & 0.121 & 0.144 & 0.142 \\
& $(0.090)$ & $(0.089)$ & $(0.089)$ & $(0.098)$ & $(0.097)$ & $(0.097)$ \\
TGxReform & -0.0415 & -0.0301 & -0.0321 & -0.100 & -0.0984 & -0.0995 \\
& $(0.092)$ & $(0.090)$ & $(0.090)$ & $(0.097)$ & $(0.095)$ & $(0.095)$ \\
TGxReform(t+1) & 0.0320 & 0.0120 & 0.00588 & 0.130 & 0.0588 & 0.0512 \\
& $(0.160)$ & $(0.089)$ & $(0.085)$ & $(0.166)$ & $(0.090)$ & $(0.086)$ \\
\hline$N$ & 4,390 & 5,338 & 5,442 & 3,745 & 4,553 & 4,633 \\
$R^{2}$ & 0.030 & 0.024 & 0.026 & 0.036 & 0.031 & 0.034 \\
\hline \hline
\end{tabular}

Note: Fixed effects (FE) estimations, clustered standard errors in parentheses; ${ }^{*} p<0.10,{ }^{* *} p<$ $0.05,{ }^{* * *} p<0.01$; TG $=1$ if $5-19$ and TG $=0$ if $20-199$; Reform $=[1$ if year $>=$ reform year $]$; $\operatorname{Reform}(\mathrm{t}-1)=[1$ if year $>=$ one year before the reform year $]$; Reform $(\mathrm{t}+1)=[1$ if year $>=$ one year after the reform year]; Sample B: remain temporary(temp)/permanent(perm) (workers who remain in a temporary/permanent job over the sample period), stayers (workers who remain in TG or CG over the sample period) or movers (workers who are allowed to switch between TG or CG over the sample period); less employable (less empl): sample of workers who perceive it to be practically impossible or difficult to find a new job; Sample period ends in January(Jan), May or December (Dec); Controls: reform dummies, TG, year fixed effects; Socio-demographic (sociodemo.) controls: log of monthly HH income, working hours, working hours ${ }^{2}$, age, age ${ }^{2}$, education, female, married, child dummies as well state fixed effects. 


\section{Newly hired permanent workers}

The EPLP reforms changed EPLP for new hires with a permanent contract but not (less) for incumbents in a permanent work relation. In particular, the 1996 abolishment of EPLP for small firms was only applied to workers who signed their contracts after September 1996; for incumbents, only a future reduction (after September 1999) in EPLP became effective on the 1st October 1996. The 1999 reform increased EPLP for new hires and workers who signed the permanent contract after September 1996, while for incumbents only an increase in future EPLP became effective.

Therefore, I restrict the samples to newly hired workers. For the 1996 reform, I only include permanent workers who signed a new contract between October 1996 - 1998 or between May 1994 - September 1996. For the 1999 reform, I only include those, who signed the contract between October 1996-1998 or 1999 - March 2001. Table 13 (lower part) presents the results in columns (3) and (6). Importantly, the number of observations becomes considerably low, specifically for the 1996 reform (371 observations). Therefore, these samples are not employed for the main analyses in the paper. Table 13 shows that the policy effect (TGxReform) is negative for the decrease in EPLP [column (3)], while it is positive for the increase in EPLP [column (6)]. Both effects, however, are not significant in statistical terms.

\section{E Non-response in job satisfaction and perceived job security}

In this section, I present the robustness of the negative EPLP effect on life satisfaction on temporary workers by accounting for non-responses in job satisfaction as well as in perceived job security. For example, the sample size is reduced by around $7 \%$ in the case of temporary workers for the 1996 reform (Sample B). ${ }^{40}$ Results are presented in Table 13 columns (1) versus (4), and columns (3) versus (6). When I compare the results for samples excluding those observations, the policy effect for the 1996 reform becomes smaller in absolute terms but remains negative.

\footnotetext{
${ }^{40}$ Results for Sample A are available upon request.
} 
Table 13: Dependent variable: life satisfaction and sample restrictions (workers who remain in contract)

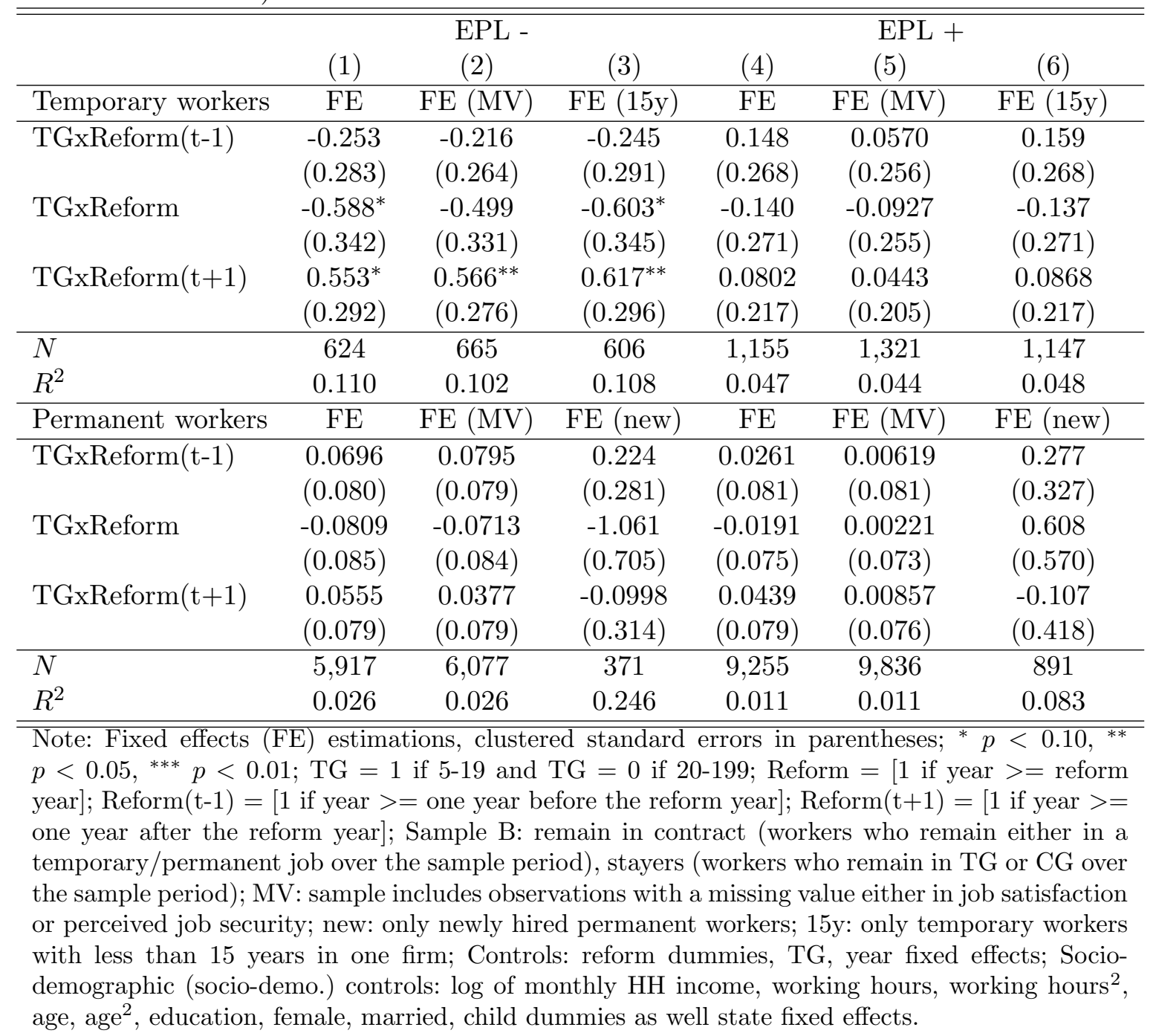

